\title{
Cortical Interneuron Subtypes Vary in Their Axonal Action Potential Properties
}

\author{
(A)Amanda E. Casale, Amanda J. Foust, Thierry Bal, and David A. McCormick \\ Department of Neurobiology, Kavli Institute for Neuroscience, Yale University School of Medicine, 333 Cedar Street, New Haven, Connecticut 06510
}

The role of interneurons in cortical microcircuits is strongly influenced by their passive and active electrical properties. Although different types of interneurons exhibit unique electrophysiological properties recorded at the soma, it is not yet clear whether these differences are also manifested in other neuronal compartments. To address this question, we have used voltage-sensitive dye to image the propagation of action potentials into the fine collaterals of axons and dendrites in two of the largest cortical interneuron subtypes in the mouse: fast-spiking interneurons, which are typically basket or chandelier neurons; and somatostatin containing interneurons, which are typically regular spiking Martinotti cells. We found that fast-spiking and somatostatin-expressing interneurons differed in their electrophysiological characteristics along their entire dendrosomatoaxonal extent. The action potentials generated in the somata and axons, including axon collaterals, of somatostatin-expressing interneurons are significantly broader than those generated in the same compartments of fast-spiking inhibitory interneurons. In addition, action potentials back-propagated into the dendrites of somatostatin-expressing interneurons much more readily than fast-spiking interneurons. Pharmacological investigations suggested that axonal action potential repolarization in both cell types depends critically upon Kvl channels, whereas the axonal and somatic action potentials of somatostatin-expressing interneurons also depend on $\mathrm{BK} \mathrm{Ca}^{2+}$-activated $\mathrm{K}^{+}$channels. These results indicate that the two broad classes of interneurons studied here have expressly different subcellular physiological properties, allowing them to perform unique computational roles in cortical circuit operations.

Key words: action potential; cortex; d-current; fast spiking; interneuron; SOM

\section{Significance Statement}

Neurons in the cerebral cortex are of two major types: excitatory and inhibitory. The proper balance of excitation and inhibition in the brain is critical for its operation. Neurons contain three main compartments: dendritic, somatic, and axonal. How the neurons receive information, process it, and pass on new information depends upon how these three compartments operate. While it has long been assumed that axons are simply for conducting information from the cell body to the synapses, here we demonstrate that the axons of different types of interneurons, the inhibitory cells, possess differing electrophysiological properties. This result implies that differing types of interneurons perform different tasks in the cortex, not only through their anatomical connections, but also through how their axons operate.

\section{Introduction}

Cortical neurons receive synaptic inputs along their dendritic/ somatic/proximal axonal compartments and convert these into a

\footnotetext{
Received April 5, 2013; revised Sept. 4, 2015; accepted Sept. 29, 2015.

Author contributions: A.E.C., A.J.F., T.B., and D.A.M. designed research; A.E.C., A.J.F., and T.B. performed research; A.E.C., A.J.F., and T.B. analyzed data; A.E.C., A.J.F., T.B., and D.A.M. wrote the paper.

This work was supported by National Institutes of Health/National Institute of Neurological Disorders and Stroke 5R01NS026143 to D.A.M., the Ruth L. Kirschstein NRSA Award to A.J.F., the CNRS to T.B., Philippe Foundation to T.B., the Agence Nationale de la Recherche to T.B., the NeuroSaclay and I code Institute projects of the IDEX Paris-Saclay to T.B., and EC contract BrainScales to T.B. We thank Babak Tahvildari and Markus Wolfel for technical assistance with the transgenic mouse lines; and Dejan Zecevic and Marko Popovic for guidance on VSD methodology.

The authors declare no competing financial interests.

Correspondence should be addressed to Dr. David A. McCormick, Department of Neuroscience, Kavli Institute for Neuroscience, Yale University School of Medicine, 333 Cedar Street, New Haven, CT 06510. E-mail: david.mccormick@yale.edu.
}

pattern of action potential discharge in their axon initial segments (Stuart and Sakmann, 1994; Stuart et al., 1997; Shu et al., 2007a; Hu et al., 2010; Hu and Jonas, 2014). The contribution of each cell type to cortical network processing is determined by the anatomical connectivity, postsynaptic influence, and the membrane properties of its soma, axonal, and dendritic arbors. Immunohistochemical studies reveal variation in localization of

A.E. Casale's present address: Systems Neurobiology Labs, The Salk Institute for Biological Studies, La Jolla, CA 92037.

A.J. Foust's present address: Centre for Neurotechnology and Department of Bioengineering, Imperial College London, South Kensington, London, SW7 2AZ, UK.

T. Bal's present address: UNIC CNRS FRE 3693, Gif-sur-Yvette, 91198, France.

DOI:10.1523/JNEUROSCI.1467-13.2015

Copyright $\odot 2015$ the authors $\quad 0270-6474 / 15 / 3515555-13 \$ 15.00 / 0$ 
different ionic channels within the axons, dendrites, and somata of different cortical cell types (Sekirnjak et al., 1997; Chow et al., 1999; Trimmer and Rhodes, 2004; Lorincz and Nusser, 2008; Debanne et al., 2011). While somatic whole-cell patch recordings have revealed striking differences in action potential kinetics between neuronal subtypes, the small diameter of axons and dendrites, particularly in the fine dendritic and axonal branches of cortical interneurons, has made it difficult to routinely record from these structures to directly assess the role of different channel distributions on a process' electrical properties (Martina et al., 2000; Kaiser et al., 2001; Hu et al., 2010, 2014; Hu and Jonas, 2014; Li et al., 2014). This limitation can be alleviated through the use of recent advances in voltage-sensitive dye (VSD) imaging techniques (Djurisic et al., 2004; Canepari et al., 2010; Foust et al., 2010, 2011; Popovic et al., 2011).

Two of the major populations of cortical interneurons that have been defined in the mouse are parvalbumin (PV)-expressing and somatostatin (SOM)-expressing cells, which make up $50 \%$ and $30 \%$, respectively, of cortical GABAergic interneurons (Xu et al., 2010; Rudy et al., 2011). These two groups have unique electrophysiological properties and form distinct synaptic connections with pyramidal cells of the cortex. PV-expressing interneurons exhibit somatic action potentials that are unusually short in duration and are often referred to as fast-spiking (FS) interneurons (McCormick et al., 1985; Ascoli et al., 2008; Hu and Jonas, 2014). FS interneurons are typically basket or chandelier GABAergic cell types, and their axons target the proximal dendrites, somata, and axon initial segments of nearby pyramidal cells (McCormick et al., 1985; Ascoli et al., 2008; Hu and Jonas, 2014). SOM-expressing interneurons, which are typically Martinotti cells, show regular spiking (RS) activity patterns with broad action potentials. In contrast with FS cells, SOM-expressing interneurons target the distal portions of pyramidal cell dendrites (Kawaguchi and Kubota, 1996; Wang et al., 2004; Halabisky et al., 2006; McGarry et al., 2010; Perrenoud et al., 2013).

FS interneurons are capable of generating high-frequency $(>300 \mathrm{~Hz})$ trains of relatively short duration (e.g., $<0.5 \mathrm{~ms}$ at half amplitude) action potentials with little spike frequency adaptation, as recorded from their somata (McCormick et al., 1985; Kawaguchi, 1993b, 1995; Wang et al., 2002; Nowak et al., 2003; Szabadics et al., 2006; Hu and Jonas, 2014). In contrast, SOM interneurons are typically characterized by an RS somatic electrophysiological signature consisting of, on average, relatively broad action potentials ( $>0.5 \mathrm{~ms}$ at half amplitude), spike frequency adaptation, and maximal firing rates of $<200 \mathrm{~Hz}$ (Kawaguchi and Kubota, 1996; Halabisky et al., 2006; Ma et al., 2006; Xu et al., 2006; McGarry et al., 2010). Whether or not these electrophysiological differences are also expressed in the axon of these two cell types is functionally important because electrophysiological properties in the axon and presynaptic terminals contribute significantly to the conversion of dendrosomatic membrane potential deviations into synaptic transmission onto the neuron's postsynaptic partners.

Here, we demonstrate that cortical SOM (RS) and FS interneurons differ not only in the duration of their action potentials at the somatic, but also axonal level, and vary in the ability of action potentials to back-propagate into their dendrites. These differences appear to result, at least in part, from differential expression of potassium channels. Furthermore, we establish the feasibility of using VSD in the physiological exploration of currently electrophysiologically inaccessible portions of cortical inhibitory interneurons (e.g., fine axonal branches). Our observations indicate that the cortical interneuron subtypes studied here have differing physiological properties along their dendrosomatoaxonal axes, which inevitably contribute to their ability to perform distinct circuit level computations.

\section{Materials and Methods}

Slice preparation and maintenance. Coronal slices of somatosensory cortex from homozygous GIN mice (FVB-Tg (GadGFP) 45704 Swn/J; stock \#003718; The Jackson Laboratory), which express GFP in a subset of somatostatin-containing interneurons (Oliva et al., 2000) or entorhinal cortical slices from hemizygous RCAN2-GFP-expressing mice (RCan2; STOCK Tg (Rcan2-EGFP) EI79Gsat; stock \#010591-UCD; GENSAT), which express GFP in fast-spiking interneurons with relatively minor overlap with non-FS neurons (Tahvildari et al., 2012), were prepared in accordance with national and institutional guidelines. Male or female mice (21- to 38-d-old; GIN average age: 31 -d-old; RCAN2 average age: 26 -d-old) were deeply anesthetized with sodium pentobarbital $(50 \mathrm{mg} /$ $\mathrm{kg}$ ) and killed through decapitation. The brain was rapidly removed and placed in ice-cold $\left(<5^{\circ} \mathrm{C}\right)$ cutting solution containing the following (in mM): 110 choline chloride, $2.5 \mathrm{KCl}, 7.0 \mathrm{MgCl}_{2}, 0.5 \mathrm{CaCl}_{2}, 25 \mathrm{NaHCO}_{3}$, $1.25 \mathrm{NaH}_{2} \mathrm{PO}_{4}, 20$ dextrose. Brain slices, $300 \mu \mathrm{m}$ thick, were cut on a Leica microslicer (model VT1000S) in ice-cold cutting solution and transferred to a $35^{\circ} \mathrm{C}$ incubation chamber containing artificial CSF (in $\mathrm{mm}$ ) as follows: $126 \mathrm{NaCl}, 3.0 \mathrm{KCl}, 1 \mathrm{MgCl}_{2}, 2 \mathrm{CaCl}_{2}, 26 \mathrm{NaHCO}_{3}, 1.25$ $\mathrm{NaH}_{2} \mathrm{PO}_{4}, 10$ dextrose, 3 myo-inositol, $2 \mathrm{Na}$-pyruvate, and 0.4 L-ascorbic acid. Slices were allowed to incubate for at least $1 \mathrm{~h}$ before dye loading and recording in a submersion chamber.

Cell selection. The VSD imaging system is constructed around an upright microscope (Olympus BX51WI) equipped to switch between three different imaging systems: (1) confocal epifluorescence for cell selection and morphological reconstruction (Yokogawa CSU-22; Solamere Technology); (2) infrared-differential interference contrast video microscopy for establishing whole-cell recordings; and (3) wide-field epifluorescence for VSD imaging. Slices were initially examined with the confocal imaging system to determine morphological completeness of individual GFPpositive cells using an optically pumped semiconductor laser (Sapphire 488-20, Coherent). Suitable cells for wide-field VSD imaging had intact dendritic and axonal arbors lying in a single focal plane located within 50 $\mu \mathrm{m}$ of the slice surface. These criteria ensure that large portions of dendritic and axonal arbors can be monitored simultaneously with minimal degradation of the image from light scattering in the tissue. Axons and dendrites were first identified based on structure diameter. The dendritic diameter was qualitatively larger than that of axons. Once a process was identified as a potential axon or dendrite, we followed the extent of the process to determine branching patterns. Axons were identified as thin processes with branches issuing at $\geq 90^{\circ}$ with respect to the primary shaft (see Fig. 1). Axons often branched at obtuse angles forming collaterals directed back toward the cell body. In contrast, dendritic branches formed angles $<90^{\circ}$ and thus continued elaborating along trajectories oriented away from the soma. For both cell types, we observed in a subset of neurons the axon-shaped appendage issuing from a primary dendrite and not the soma directly (SOM (RS): $25 \%$ and FS: $16 \%$ dendritic axon origin). Dendrite originating axons were only excluded from studies involving propagation speed and from analysis of dendritic action potential trains. These criteria for identifying axons and dendrites yielded consistent pharmacological and electrophysiological differences observed here and were confirmed through microscopic examination of biocytin-filled neurons $(n>24)$ of both SOM and FS interneurons (Tahvildari et al., 2012).

VDS loading and recording. Suitable GFP-positive neurons were loaded with the VSD JPW3028 (available from Invitrogen as D-6923) through a glass patch electrode by filling the tip with dye-free internal solution (in mM as follows: $130 \mathrm{~K}$-gluconate, $7 \mathrm{KCl}, 4 \mathrm{ATP}-\mathrm{Mg}$, $0.3 \mathrm{GTP}$ $\mathrm{Na}, 10$ phosphocreatine-Na, 10 HEPES, $0.4 \%$ biocytin, adjusted to $\mathrm{pH}$ 7.4 and $284 \mathrm{mOsm}$ ), and back-filling with dye-containing internal solution $(400-800 \mu \mathrm{M})$. Dye-free solution in the tip of the patch electrode was necessary to prevent spilling the highly lipophilic dye onto the slice before patching the cell of interest. Dye bound to membrane outside the cell of interest would increase the background fluorescence $(F)$, thus 
degrading recording sensitivity. A whole-cell somatic recording was obtained from the selected neuron at room temperature $\left(22^{\circ} \mathrm{C}\right)$ under infrared-differential interference contrast optics, and the dye was allowed to diffuse into the cell for 15-30 min. After filling, the patch electrode was removed from the neuron forming an outside-out patch, and the cell was incubated at $35^{\circ} \mathrm{C}$ for at least $1 \mathrm{~h}$, allowing the dye to diffuse from the soma into distal processes. The filled neuron was then repatched near physiological temperature $\left(35^{\circ} \mathrm{C}\right)$ with a dye-free patch electrode for simultaneous optical and electrophysiological recording. Before beginning optical recordings, we confirmed the physiological properties of the filled cells. RCAN2-positive FS cells were identified by their short duration action potentials, which exhibited little or no spike-frequency adaptation during trains of action potentials (500 ms step depolarizations). We also performed 50 or $150 \mathrm{~ms}$ step hyperpolarizations to confirm fast membrane time constants. All RCAN2 units included in the analyses had stereotyped FS characteristics. In the GIN line, there is a small overlap $(\sim 30 \%)$ in cortex of somatostatin-positive units that coexpress calretinin but have similar Martinotti morphology (Xu et al., 2006). Analysis of dendritic and axonal properties failed to show differences in measured parameters across the population and all units were subsequently included in the GIN population.

VSD-filled neurons were illuminated with a $450 \mathrm{~mW}$ frequencydoubled diode-pumped Nd:YVO4 low-noise laser emitting at $532 \mathrm{~nm}$ (MLL532; Changchun New Industries Optoelectronics Technology). The laser beam was directed to a light guide coupled to the microscope via a single-port epifluorescence condenser (TILL Photonics) designed to overfill the back aperture of the objective, enabling nearly uniform illumination at the object plane. Somatic illumination was limited by the microscope field-stop to minimize damage to the recorded neuron. Fluorescence from the stained cell was collected through the objective $(60 \times$ water-immersion; 1.0 numerical aperture; Nikon), long-pass filtered (RG610 HP; Schott), and projected onto an $80 \times 80$ pixel high-speed CCD camera with a $20 \mathrm{kHz}$ maximum frame rate (NeuroCCD-SMQ; RedShirtImaging) mounted at the front camera port of the trinocular tube. At the magnifications that we used, each pixel of the camera corresponded to a square region of 4 or $1 \mu \mathrm{m}$ per side, depending on the installation of either a $0.3 \times$ or $0.1 \times$ coupler (Optem serial \#25-70-12 and RL091301-1). Changes in VSD fluorescence were recorded in response to action potentials initiated by intrasomatic current injections (single $50 \mathrm{~ms}$ step depolarization or train of $5 \mathrm{~ms}$ step depolarizations at a frequency of $100 \mathrm{~Hz}$ ). For high temporal resolution assessment of action potential kinetics, we used CCD frame rates of $10 \mathrm{kHz}(80 \times 12$ pixels) or $20 \mathrm{kHz}(26 \times 4$ pixels). At these temporal and spatial acquisition frequencies, single-to-noise ratio $(\mathrm{S} / \mathrm{N}) \geq 8$ was typically achieved in single passes or by averaging small numbers $(2-4)$ of trials. It has previously been determined in multiple cell types that the introduction of the VSD used here (JPW3028) does not alter intrinsic membrane properties, including input resistance, capacitance, or shape and kinetics of action potential generation (Canepari et al., 2007, 2010; Foust et al., 2010, 2011; Casale and McCormick, 2011; Popovic et al., 2011). In agreement with this lack of effect on membrane or action potential properties, our values for action potential widths for fast-spiking and SOM subtypes of interneurons were not statistically significantly different from those previously reported for non-dye-loaded interneurons of the same type (Ma et al., 2006; Tahvildari et al., 2012).

To determine the influence of specific potassium channel subtypes on action potential kinetics in the somata and axons of SOM (RS) and FS interneurons, we performed experiments using potassium channel blockers. We bath applied tetraethylammonium chloride (TEA; $1 \mathrm{~mm}$, Sigma-Aldrich), $\alpha$-dendrotoxin ( $\alpha$-DTX; 100 nм, Alomone Labs; a specific blocker of Kv1 channels), iberiotoxin (IBTX; 100 nм Sigma-Aldrich; a blocker of large conductance calcium-activated potassium channels; BK channels), or paxilline (PAX; $5 \mu \mathrm{m}$, Tocris Bioscience; a potent blocker of large conductance calcium-activated potassium channels; BK channels). For toxin experiments, we first acquired 4 or 5 control trials over a period of 5-10 $\mathrm{min}$ in the axon in response to somatically elicited action potentials. We then commenced bath application of the drug, waiting 10-20 min before acquiring 5-10 trials over the following 20-40 $\mathrm{min}$. Drugs were subsequently washed out for at least $20-40 \mathrm{~min}$ before acquiring 3-5 more trials from the same axonal region. For IBTX and $\alpha$-DTX, we attempted washouts ( $\sim 40 \mathrm{~min})$ for 2 cells in each group. We were unable to wash out the effects of these drugs, and so we have omitted the wash condition from example traces and time dependence plots in Figure 5 . The effects of TEA were found to be at least partially reversible in all tested neurons, and we have included sample washout traces and washout time dependence in Figure 5. The chamber flow rate was measured at $\sim 4.5 \mathrm{ml} / \mathrm{min}$. The effects of potassium channel blockers on action potential duration were assessed by examining the changes in action potential waveform from the same pixels before, during, and following washout of each manipulation. Changes in action potential duration are presented as mean percentage change \pm SEM.

For subthreshold depolarization experiments (see Fig. 6), VSD-filled cells were depolarized through somatic current injection by $10-20 \mathrm{mV}$. Depolarizations lasted for $\sim 10 \mathrm{~s}$ before a brief $(5 \mathrm{~ms})$ current injection identical to that used during resting membrane trials was delivered to induce an action potential. Depolarization trials were interleaved with trials recorded at resting membrane potentials with $1 \mathrm{~min}$ intertrial intervals. We also changed the starting condition (resting membrane or depolarized) between cells to account for any potential recording bias. Reported voltages are corrected for the liquid junction potential, which was calculated as $\sim 14 \mathrm{mV}$.

To compare the propagation and kinetics of the action potential across subcellular compartments and between interneuron types, we increased $\mathrm{S} / \mathrm{N}$ by averaging fluorescence signals in regions of interest (ROIs) spanning $\sim 15-21 \mu \mathrm{m}$ lengths of dendrite or axon. For each ROI, we measured the soma-to-ROI (center-to-center) path length along the interrogated axon or dendrite (ImageJ, National Institutes of Health). This length of pixel averaging results in the inability to precisely determine the point of action potential initiation in axons as it precludes short distance evaluations. However, these pixel stretches do suggest a proximal axonal region for action potential initiation, similar to those observed with electrical recordings (Hu et al., 2014; Li et al., 2014). For FS axons, we often imaged axon collaterals that could not be easily traced along the axon to the soma due to the highly branching and sinuous nature of these processes. In this case, we computed the linear distance in micrometers of the recorded region to the soma and report this value as the "estimated soma-to-ROI distance," denoted with gray circles in Figure 3. This strategy, although useful for comparing the kinetics along the extent of FS neuron axons, certainly underestimates the true soma-toROI distance.

Each imaging trial lasted between 20 and $50 \mathrm{~ms}$, and the VSD was illuminated only during this period, with intertrial intervals of at least 1 min. Dendritic and axonal arbors tolerated between 10 and 20 such trials before changes in the somatic electrophysiological properties of the recorded neuron (action potential amplitude and duration, resting membrane potential, resting input resistance) were detected $(>10 \%$ of baseline values) indicating photodynamic damage, in which case the experiment was terminated. These trial numbers were determined empirically by imaging filled units from our cell populations of interest and recording the somatic voltage changes. For GIN cells, we found most units tolerated $10-15$ trials before changes ( $>10 \%$ of baseline) in somatic action potential kinetics were observed (average percentage change [mean \pm SEM] after $10-15$ trials: width: $3.2 \pm 2.8 \%$, rise time: $-0.03 \pm$ 2.2; fall time: $4.1 \pm 2.6 \%$, amplitude: $-0.74 \pm 3.1 \% ; n=7$ cells, $p>0.9$, two-tailed Wilcoxon signed-rank test). RCAN2 (FS) units tolerated even greater numbers (15-20) of trials before changes in somatic action potential waveform were observed (average percentage change [mean \pm SEM] after $15-20$ trials: width: $2.6 \pm 3.3 \%$; rise time: $-1.8 \pm 3.6$; fall time: $2.9 \pm 6.1 \%$; amplitude: $-1.4 \pm 3.8 \% ; n=10$ cells, $p>0.7$, twotailed Wilcoxon signed-rank test). After experimentation, confocal $z$-stacks were taken through the VSD-filled interneuron to discern the fine structural details of the dendritic and axonal arbors.

Data analysis. The methods for analyzing data obtained from the VSD used here have been published previously (Canepari et al., 2007, 2010; Foust et al., 2010, 2011; Popovic et al., 2011). The S/N of imaged voltage deflections varied from cell to cell depending on dye concentration, depth of scattering tissue between the image process and slice surface, and nonspecific background fluorescence emanating from nearby, out- 


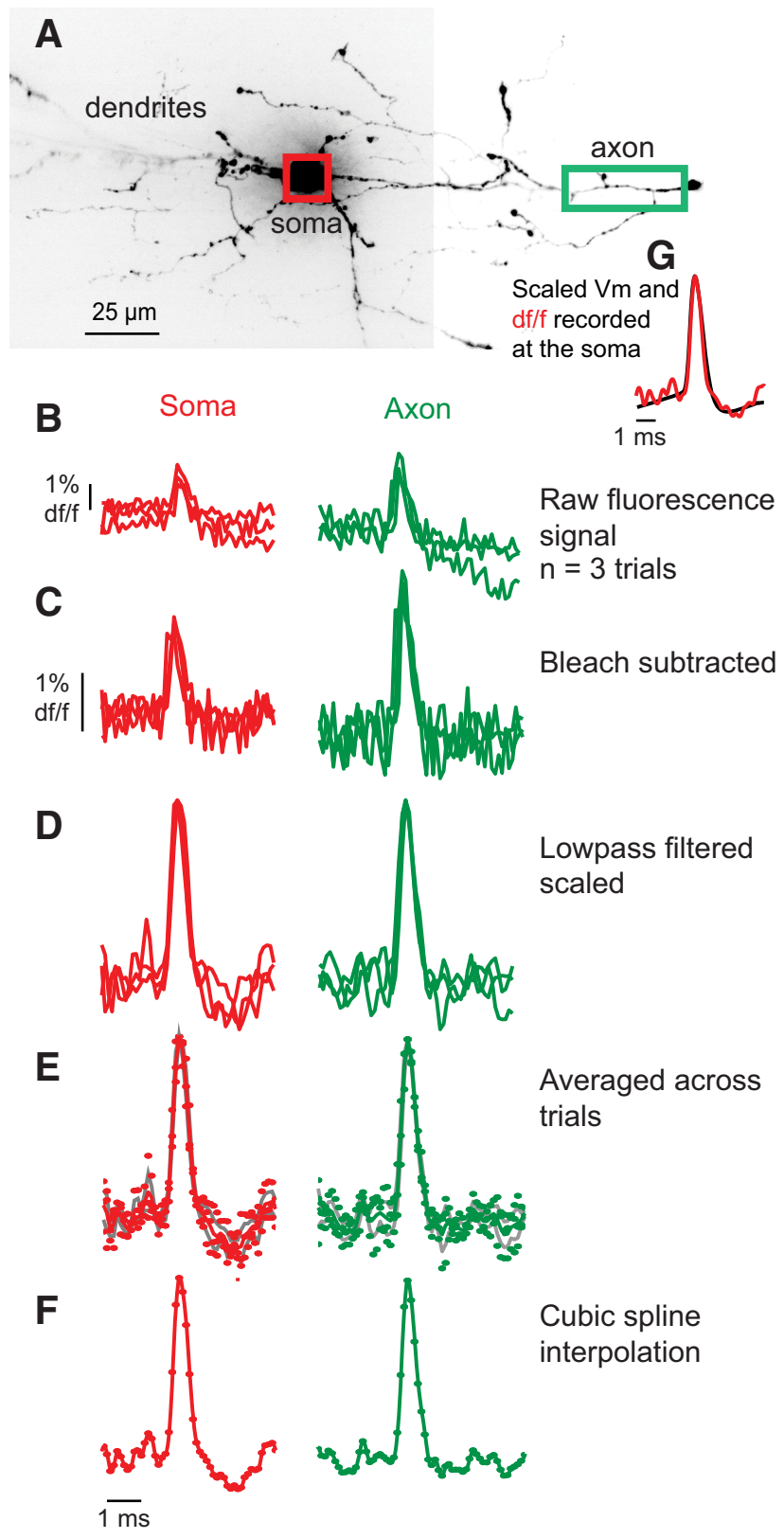

Figure 1. Illustration of method for calculation of the average optically recorded action potential waveform in soma and axon of an SOM-expressing (RS) interneuron. $A$, Confocal $z$-projection of an SOMexpressing (RS) interneuron. Regions used for VSD recording induded the cell body (red box) and main axon (green box) as indicated. The axon was identified as the process that gives rise to multiple thin processes, some of which turned back toward the cell body. $\boldsymbol{B}$, Raw, unfiltered signal from the two regions shown in $\boldsymbol{A}$ (red represents soma; green represents axon). Data are the spatial average of the pixels over the soma and axon within the indicated regions (red and green boxes). Raw traces were aligned using the electrical signal, as described in Materials and Methods. C, Same as in B, except that the trend line corresponding to photobleaching is subtracted. $\boldsymbol{D}$, Data in Clow pass filtered with a binomial filter, and then each action potential is scaled to the same peak height. $\boldsymbol{E}$, Bleach subtracted, filtered, and scaled traces are averaged. The average (solid line with \pm SEM as gray lines) action potentials are plotted. $F$, Values between the average points are calculated with cubicsplineinterpolation at $100 \mathrm{kHz}$. G,Overlay of theaction potential in the soma as recorded with the whole-cell pipette and VSD, illustrating the high degree of accurate representation of the action potential waveform by the dye.

of-focus structures. Thus, to increase $\mathrm{S} / \mathrm{N}$ to at least 8 , we averaged fluorescence changes from groups of neighboring pixels (8-60 pixels) across small numbers (1-4) of trials. To avoid smearing in the trial-to-trial average because of temporal jitter in spike initiation, for each trial we shifted the signal in each pixel by the time needed to align the peak of the electrically recorded somatic action potential (Fig. 1). Within trial bleaching and low-frequency noise were removed by subtracting an exponential or polynomial function fit to the raw fluorescence signal (Fig. $1 B, C)$. A low-pass binomial filter (1-2 weight) was applied to reduce high-frequency noise (Fig. 1D). The waveforms of multiple trials under the same conditions were averaged (Fig. 1E). Finally, waveforms were cubic spline interpolated to $100 \mathrm{kHz}$ for precise estimation of spike kinetics (e.g., width, 10\%-90\% rise time, $90 \%-10 \%$ fall time) (Fig. $1 F$ ). These procedures resulted in a VSD waveform that closely tracked that recorded electrically (Fig. $1 G$ ).

The width of the spike-associated fluorescence change was measured at the half-maximum amplitude. The $10 \%-90 \%$ rise time of the fluorescence change was determined by calculating the difference between the time of $10 \%$ and $90 \%$ of the maximum amplitude of the fluorescence change from the preceding baseline fluorescence. We could not use $\mathrm{dF} / \mathrm{dt}$ to determine peak rate of change because fluorescence was not measured at a rate that had high enough temporal resolution to determine peak changes in action potential shape, and fluorescence is not scaled to an absolute voltage. Non-voltage-dependent background fluorescence varies with factors other than voltage (e.g., density of dye, partitioning of dye in inner and outer membranes, depth of process in tissue), precluding straightforward conversion of $d F / F$ into voltage (Salzberg et al., 1983). The dye, however, linearly follows voltage changes in the physiological range with microsecond precision (Fig. 1G) (Salzberg et al., 1993), making a comparison across compartments of the kinetics of fluorescence changes a reliable measure (Fig. $1 G$ ). This dye characteristic also makes it possible to determine propagation speed of action potentials. To quantify this, we computed the latency to half-maximum spike amplitude at different distances along the axon and dendrite compared with the timing of half-maximum amplitude observed at the soma. We restricted latency analyses to units in which the axon originated from the soma. Using linear regression on the distance-latency data, we took the inverse slope of the fit to determine propagation velocity (Fig. 2). Latencydistance plots for processes that we had determined to be axons based on morphological properties yielded regression lines with negative $y$-intercepts, suggesting that the action potential originated in the proximal axon, subsequently propagating toward both the soma and down the distal axon.

Changes in action potential shape are reported as normalized mean percentage change \pm SEM unless otherwise noted. Statistical significance was determined using parametric tests (one-way ANOVA, twotailed unpaired $t$ tests, ANCOVA) for data with sample sizes $>10$ that followed a normal distribution. For small sample sizes, for example, during drug and subthreshold testing, we restricted our statistical analyses to nonparametric tests, such as one- or two-tailed Wilcoxon signed-rank and Kruskal-Wallis tests. The test used is stated along with the $p$ value. $p$ values $<0.05$ were treated as significant.

\section{Results}

Action potential propagation and shape are markedly different between SOM-expressing (RS) and FS interneurons across their entire dendrosomatoaxonal axes

To assess the ability of action potentials to propagate into the dendritic and axonal arbors of SOM (RS) and FS interneurons, we imaged fluorescence changes at 10 or $20 \mathrm{kHz}$ in response to action potentials generated somatically by single $50 \mathrm{~ms}$ or multiple $5 \mathrm{~ms}$ (trains of $4-5$ steps at $100 \mathrm{~Hz}$ ) step depolarizations. Single action potentials elicited by somatic current injection led to action potential-shaped voltage deflections, as evidenced by changes in fluorescence, in SOM (RS) and FS interneuron dendrites, axons, and axon collaterals (Fig. 2). The shape of the action potential, and the distance to which it back-propagated into the dendrites, however, varied between the cell types.

In all cortical SOM (RS) interneurons, we found spikeshaped fluorescence changes in response to action potentials along primary, secondary, and tertiary dendritic branches, including at our most distal recording site of $\sim 150 \mu \mathrm{m}$ (Fig. $2 A$; $n=32$ cells). Dendritic propagation speed averaged $1.1 \mathrm{~m} / \mathrm{s}$ 

A SOM (RS) Dendrite
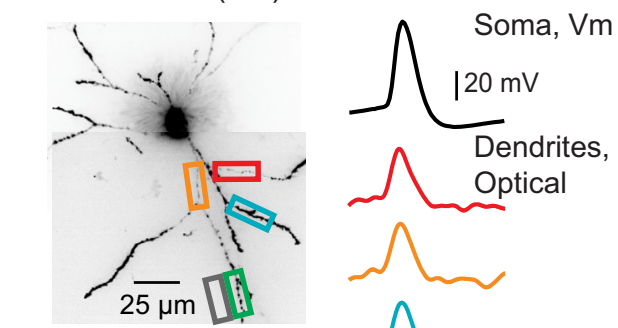

B

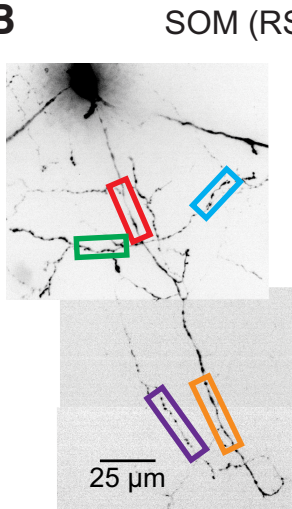

Axon
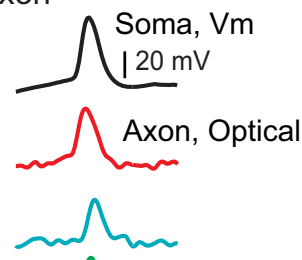

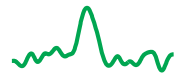

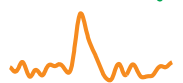

$1 \%$ $\mathrm{df} / \mathrm{f}$ thm ham

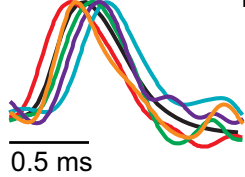

$\mathrm{ms}$
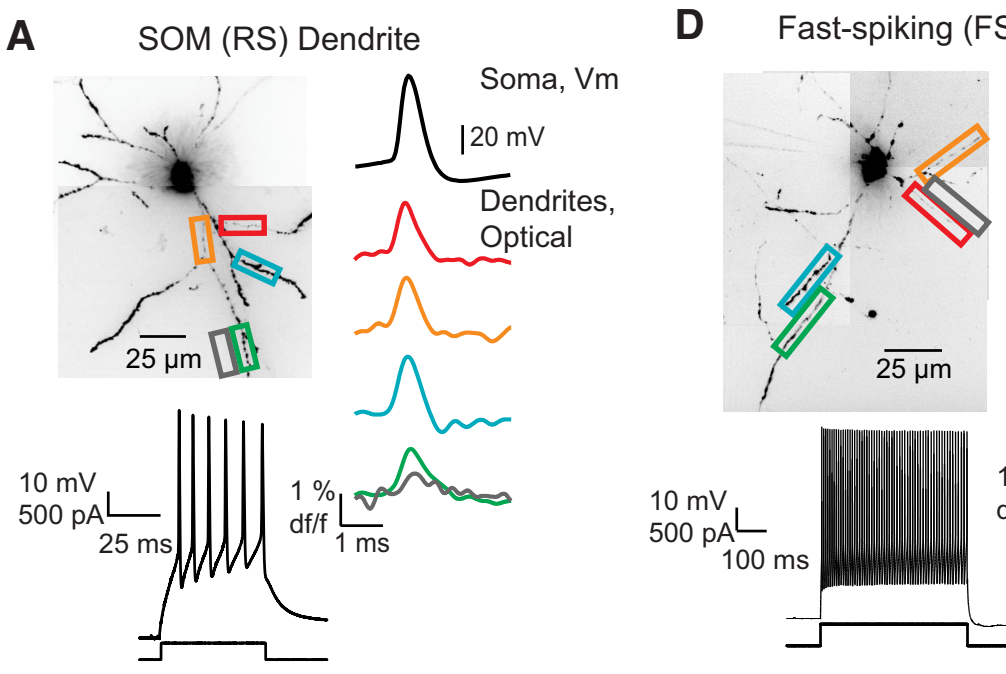

(FS) Dendrite

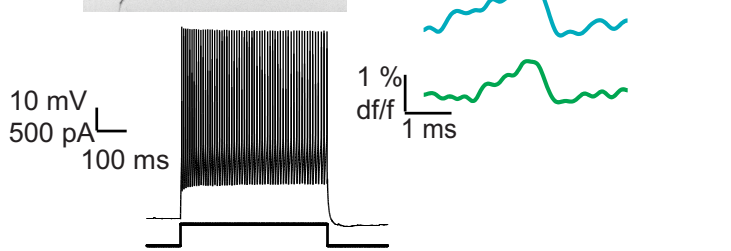

E

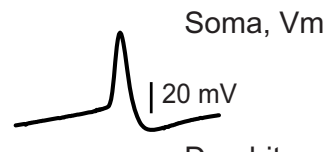

Dendrites,
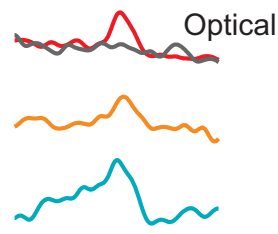

$\mathrm{df} / \mathrm{f} \frac{1}{1 \mathrm{~ms}}$

E Fast-spiking (FS) Axon
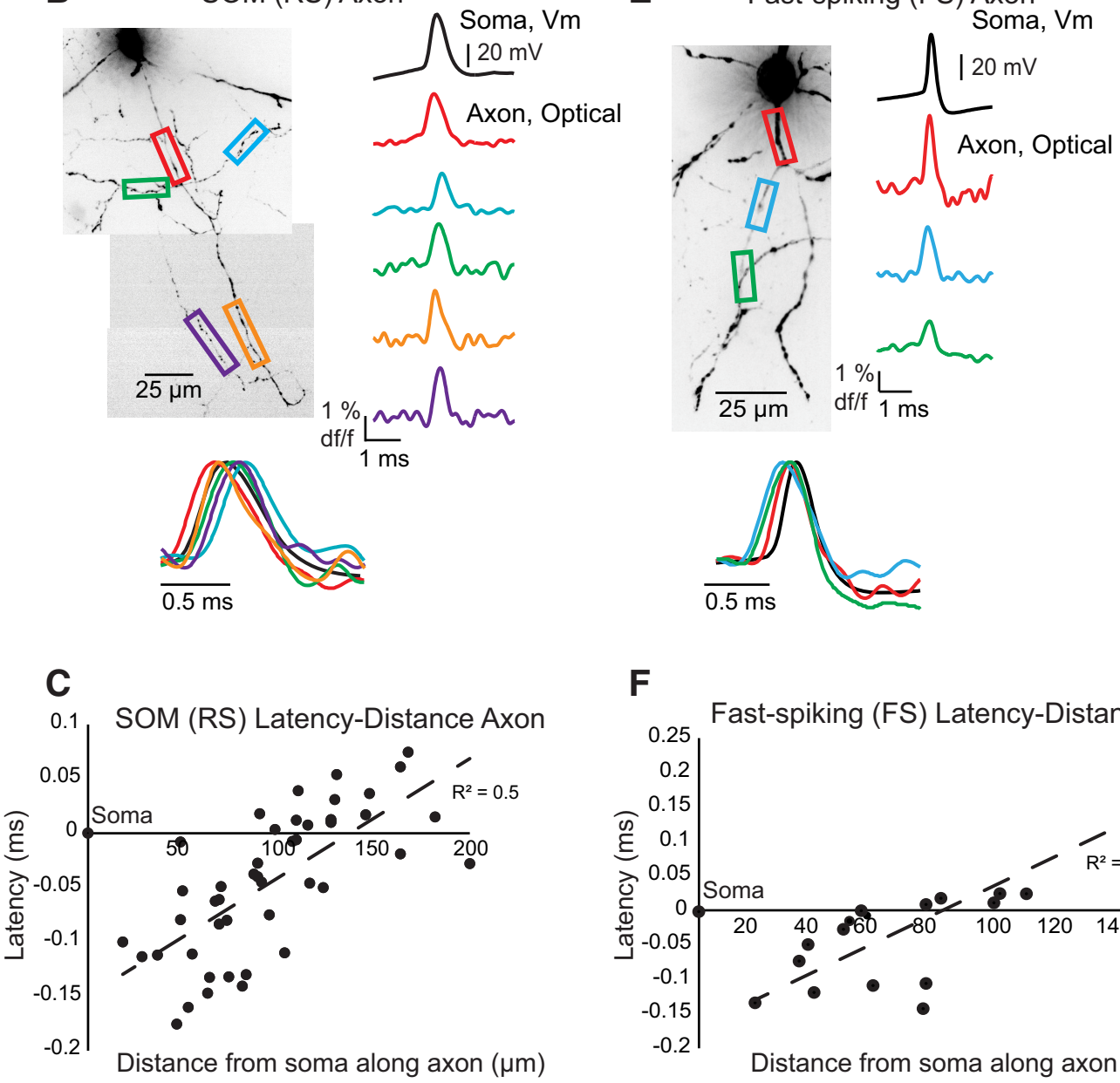

F

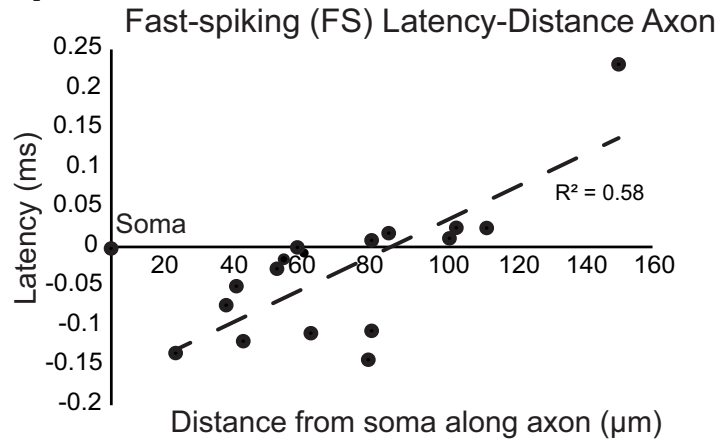

Figure 2. Action potential propagation in dendrites and axons of SOM-expressing (RS) and FS interneurons. A, Confocal z-projection of a VSD-filled SOM interneuron. Colored boxes and traces represent dendritic regions used for assessing action potential propagation. Below z-projection, Example of SOM spiking properties in response to a square pulse injected into the soma. Right, Colored traces represent average fluorescence changes (4 trials) recorded optically in interneuron dendrites and black trace shows an average of four trials recorded electrically at the soma. Gray boxes and traces represent regions outside of the dendritic arbor and were used to determine light scatter from the processes. B, Confocal z-projection of a VSD-filled SOM interneuron. Colored boxes and traces represent axonal regions used for assessing action potential propagation (average of 5 trials). Bottom, 0verlay of voltage and fluorescence traces from above cell to demonstrate spike latency between the axon and soma. $C$, Scatter plot for latency-distance along the axon of action potential half-height time relative to the somatic action potential half-height ( $n=8$ cells). Half-height occurs first in the proximal axon. $\boldsymbol{D}-\boldsymbol{F}$, Same as in $\boldsymbol{A}-\boldsymbol{C}$, but for VSD-filled FS interneuron. $\boldsymbol{D}$, Average traces are taken from 5 trials. $\boldsymbol{E}$, Average traces taken from 5 trials. $\boldsymbol{F}$, Latency-distance plot includes 10 cells. 
A SOM (RS)

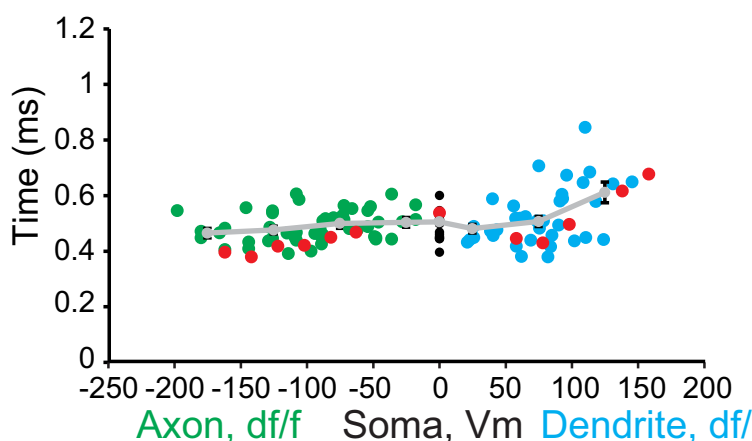

B

Fast-Spiking (FS)

\section{Width}
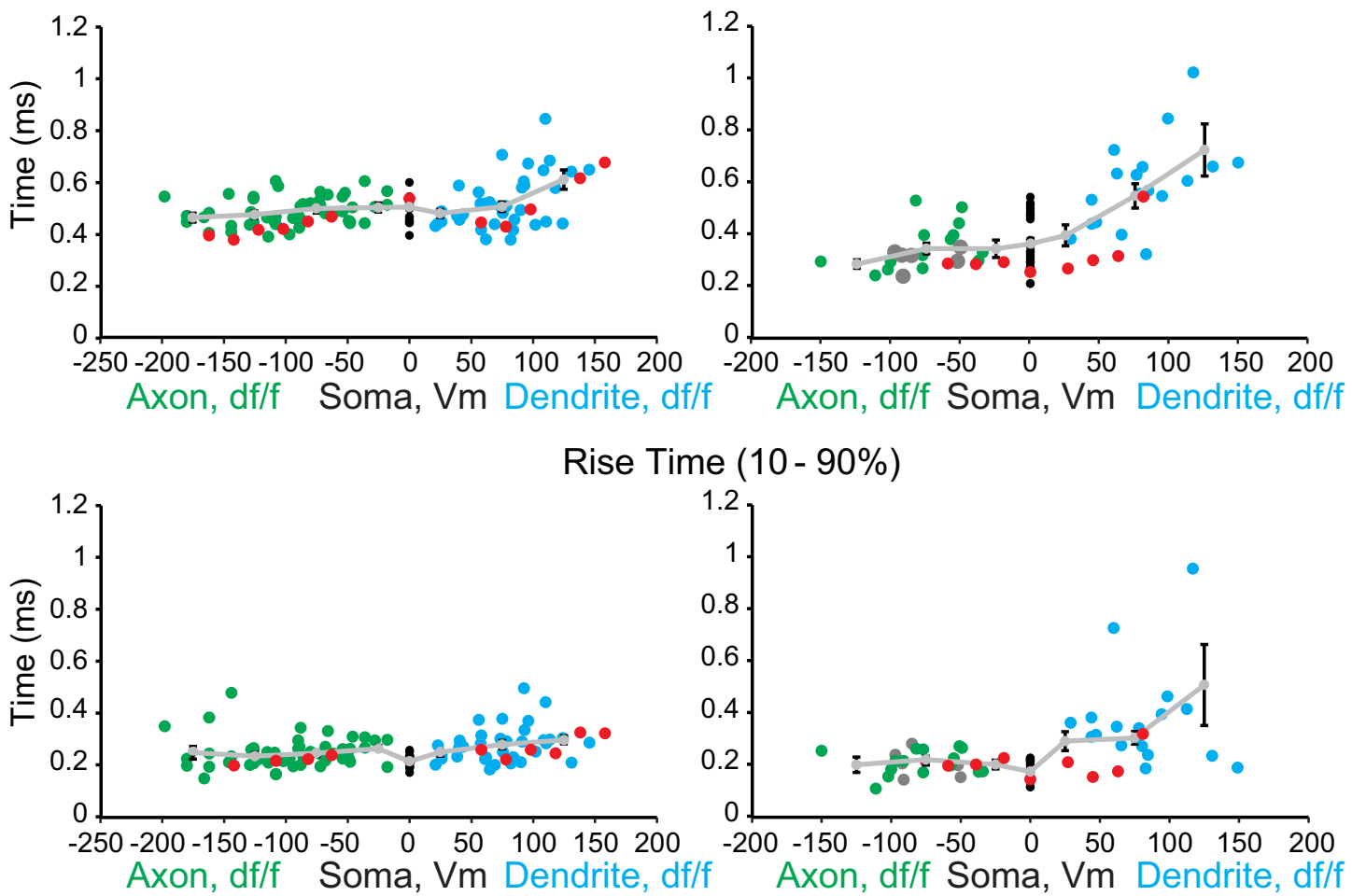

Fall Time $(90-10 \%)$
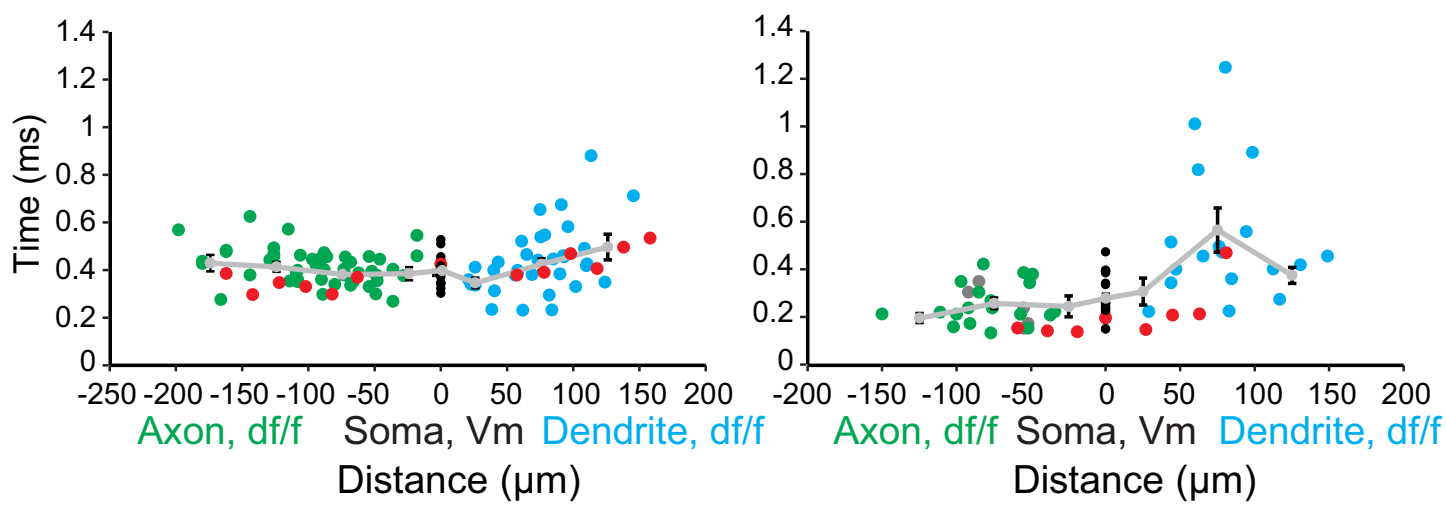

Figure 3. Axonal and somatic action potential durations are shorter in FS versus SOM-expressing (RS) interneurons. $A$, Left, Action potential width at half-amplitude, $10 \%-90 \%$ rise time, and $90 \%-10 \%$ fall time of fluorescence transients in the axon (green), dendrite (blue), and electrically recorded at the soma (black) of SOM interneurons in response to single action potentials plotted as a function of distance ( $n=18$ cells). Light gray line shows mean \pm SEM of population measures over distance in $50 \mu \mathrm{m}$ bins. $\boldsymbol{B}$, Right, Same as for $\boldsymbol{A}$, but for FS interneurons ( $n=22$ cells). Gray circles (right) represent axonal measurements calculated as linear distance from the soma ( $n=6$ cells). Red circles represent measurements recorded from a single cell in which we imaged from both a dendrite and axon.

( $n=10$ cells), similar to previous reports of hippocampal SOM-expressing neurons (Martina et al., 2000). Analysis of spike width at half-maximum amplitude revealed that the action potentials broadened during back-propagation into the dendrites (Fig. $3 A)$ : width SOM proximal dendrite $(<50 \mu \mathrm{m})$, $0.48 \pm 0.02 \mathrm{~ms}$ duration (mean \pm SEM); distal dendrite $(>100 \mu \mathrm{m}), 0.61 \pm 0.04 \mathrm{~ms}$ duration (mean $\pm \mathrm{SEM} ; n=10$ cells).

In FS interneurons, action potentials reliably elicited spikeshaped changes in fluorescence in the proximal dendrite $(<50$ $\mu \mathrm{m}$ from the soma) but appeared to fail at greater distances where fluorescence changes merged with noise fluctuations
(Fig. $2 D ; n=16$ cells). Because of the decrease in $\mathrm{S} / \mathrm{N}$ with dendritic distance, we were unable to reliably determine propagation speed. Spike width at half-maximum amplitude rapidly increased with distance along the dendrite with a slope significantly steeper than that observed in SOM (RS) dendrites: FS proximal dendrite $(<50 \mu \mathrm{m}), 0.4 \pm 0.04 \mathrm{~ms}$ duration $($ mean \pm SEM $)$; distal dendrite $(>100 \mu \mathrm{m}), 0.72 \pm 0.1 \mathrm{~ms}$ duration (mean \pm SEM) $(n=7$ FS cells; $p<0.001$, ANCOVA).

Single action potentials reliably elicited spike-shaped fluorescence transients in all imaged axons and collaterals in both cortical cell types (Fig. 2 B, E; SOM (RS), $n=39$ cells; FS, $n=$ 
24 cells). The pronounced difference observed in somatic action potential duration (FS, $0.37 \pm 0.02 \mathrm{~ms} ; n=22$ cells; SOM, $0.5 \pm 0.01 \mathrm{~ms} ; n=18$ cells; $p<0.001$, two-tailed unpaired $t$ test) was maintained well into the axons and axon collaterals (Fig. 3 ; $p<0.01$, one-way ANOVA) where synaptic connections are formed (Binzegger et al., 2004, 2005). Examining the rise and fall time of action potential waveforms revealed FS action potentials were faster rising, and especially faster falling, than those in SOM interneuron axons (Fig. 3; $p<0.03$ for both measured parameters, two-tailed unpaired $t$ test). On average, action potentials propagated at speeds of $0.6 \mathrm{~m} / \mathrm{s}$ in FS axons $(n=10)$ and $0.9 \mathrm{~m} / \mathrm{s}$ in SOM (RS) axons $(n=8)$, similar to values previously reported for unmyelinated axons in the cortex (Foust et al., 2010, 2011; Popovic et al., 2011). These speeds are slightly slower than those recently reported for the main axon of hippocampal FS interneurons ( $\mathrm{Hu}$ and Jonas, 2014), but faster than those reported for antidromic propagation in SOM and PV cortical interneurons (Li et al., 2014).

Trains of action potentials invade dendritic and axonal arbors of cortical FS and SOM (RS) interneurons with little change in kinetics

The effects of firing frequency on action potential shape and propagation have previously been reported for hippocampal FS interneuron dendrites and axons and for hippocampal SOM (RS) dendrites using traditional electrophysiological methods (Martina et al., 2000; Hu et al., 2010; Hu and Jonas, 2014). We expand on these hippocampal findings by investigating trains of action potentials generated at $100 \mathrm{~Hz}$ in cortical interneurons with VSD. Our results are similar to those previously observed electrophysiologically in the hippocampus.

In FS dendrites and axons, we found trains of action potentials (4 spikes) at $100 \mathrm{~Hz}$ elicited spike-shaped fluorescence changes in single trials (Fig. 4A). Comparing dendritic action potential kinetics between the first and fourth spike showed no significant changes in rise time, fall time, width at half-maximum amplitude, or amplitude of fluorescence change (Fig. $4 A$; dendrite, $p>0.05$, Wilcoxon signed-rank test, $n=5$ ). In both the soma and axon, kinetics between the first and fourth spike revealed no significant differences in any measured parameter (Fig. $4 A ; p>0.05$, Wilcoxon signed-rank test; soma, $n=8$; axon, $n=5$ ).

For SOM (RS) interneurons, we found $100 \mathrm{~Hz}$ stimulation also reliably generated fluorescence transients in dendrites in single trials (Fig. 4B). Comparison of dendritic action potential kinetics between the first and fourth spike elicited at a frequency of $100 \mathrm{~Hz}$ revealed no significant changes in the full width at halfmaximum, $10 \%-90 \%$ rise time, $90 \%-10 \%$ fall time, or amplitude of fluorescence change (Fig. $4 B$; dendrite, $p>0.05$, Wilcoxon signed-rank test; $n=5$ ). Analysis of the axon, which has not been previously reported, revealed reliable action potential propagation and a small, but significant, decrease in axonal action potential amplitude between the first and the fourth spike (Fig. $4 B$; axon, $\Delta F / F$ amplitude: $-11.4 \pm 3.9 \%, p=0.03$, Wilcoxon signed-rank test; $n=7$ ). At the soma, we found a significant increase in action potential duration and $10 \%-90 \%$ rise time, in addition to a significant decrease in action potential height (Fig. $4 B ; p<0.02$, Wilcoxon signed-rank test; soma, $n=7$ ).

Action potential kinetics in SOM (RS) and FS cells are differentially sensitive to potassium channel blockers

Previously, we demonstrated that different $\mathrm{K}^{+}$currents underlie action potential repolarization in the axons and somata of cortical pyramidal neurons (Shu et al., 2007b; Yu et al., 2010; Foust et al., 2011). Here, we explored whether the action potentials in cortical SOM (RS) and FS neurons are differentially sensitive to $\mathrm{K}^{+}$channel blockers in their axonal and somatic compartments.

In both SOM-expressing (RS) and FS cells, we assessed the effects of bath application of three potassium channel blockers: $\alpha$-DTX (100 nM), IBTX (100 nM), and TEA ( $1 \mathrm{~mm}), \alpha$-DTX is a selective blocker of voltage-gated potassium channels Kv1.1, 1.2, and 1.6 (Coetzee et al., 1999). These channels give rise to the low-threshold rapidly activating, slowly inactivating potassium conductance known as the D-current. D-current has been shown to regulate spike initiation threshold in the soma of FS interneurons (Goldberg et al., 2008) and influence axonal spike duration in layer 5 pyramidal cells (Kole et al., 2007; Shu et al., 2007b; Foust et al., 2011). IBTX is a relatively specific blocker of BK $\mathrm{Ca}^{2+}$-activated $\mathrm{K}^{+}$channels (Coetzee et al., 1999; Shao et al., 1999). TEA, on the other hand, is a broad-band blocker of $\mathrm{K}^{+}$ channels, although it exhibits some specificity for Kv3 and BK $\mathrm{Ca}^{2+}$-activated $\mathrm{K}^{+}$channels at low concentration (1 mM) (Lancaster and Nicoll, 1987; Chow et al., 1999; Coetzee et al., 1999).

Bath application of $\alpha$-DTX resulted in a large increase in axonal action potential duration in the axons of both SOMexpressing (RS) and FS interneurons (Fig. 5; SOM, $49.9 \pm 9.3 \%$, $n=5$ cells; FS, $49.9 \pm 20.8 \% ; n=5$ cells; $p<0.05$, one-tailed Wilcoxon signed-rank test), suggesting that Kv1 channels are critically involved in spike repolarization in both SOM (RS) and FS axons and axon collaterals. In contrast to the effects on axonal action potentials, application of $\alpha$-DTX resulted in a small increase in somatic action potential duration in SOM-expressing (RS) and FS interneurons (Fig. 5; SOM, $11.7 \pm 3.1 \%, n=5$ cells; FS, $17.7 \pm 6.9 \%, n=6$ cells; $p<0.05$, one-tailed Wilcoxon signed-rank test). For both cell types, $\alpha$-DTX-induced action potential broadening was greater in the axon than the somatic compartment ( $p<0.03$, two-tailed Wilcoxon signed-rank test).

In response to bath application of $1 \mathrm{~mm}$ TEA, action potential widths were seen to increase in the soma and axon of both SOMexpressing (RS) and FS interneurons (Fig. 5; SOM: soma, $81.8 \pm$ $18.8 \%, n=5$; axon, $60.8 \pm 21.2 \%, n=5, p<0.03$, all compartments, one-tailed Wilcoxon signed-rank test; FS: soma, $75.7 \pm$ $5.8 \%, n=6$; axon, $39.9 \pm 6.4 \%, n=5$; $p<0.01$, all compartments, one-tailed Wilcoxon signed-rank test). Interestingly, TEA-induced action potential broadening was greater in the soma than the axon for each cell type ( $p<0.03$, two-tailed Wilcoxon signed-rank test). We achieved washout of TEA from both cell types and compartments as control and washout conditions were not significantly different from each other but significantly different from the TEA condition (Fig. 5; $p<0.005$, one-way Kruskal-Wallis test for each cell type and compartment drug vs control and washout).

Application of IBTX (100 nM) resulted in differential effects in SOM (RS) and FS interneurons. In SOM (RS) interneurons, IBTX caused a significant increase in action potential duration in both the axon $(45.1 \pm 18.1 \%, n=6 ; p=0.015$, one-tailed Wilcoxon signed-rank test) and soma $(31 \pm 13.2 \%, n=6 ; p=0.015$, one-tailed Wilcoxon signed-rank test) (Fig. 5). To further confirm the role of BK channels in cortical SOM (RS) axonal action potential repolarization, we performed experiments using PAX $(5 \mu \mathrm{m})$, a highly specific blocker of BK channels, in addition to double and triple occlusion experiments. Addition of PAX to the bath solution resulted in action potential duration increases of $32 \%$ and $21 \%$ at the SOM (RS) axon $(n=2)$. In a triple occlusion experiment, addition of IBTX to the extracellular solution containing paxilline failed to further broaden the axonal action po- 
A Fast-Spiking (FS)

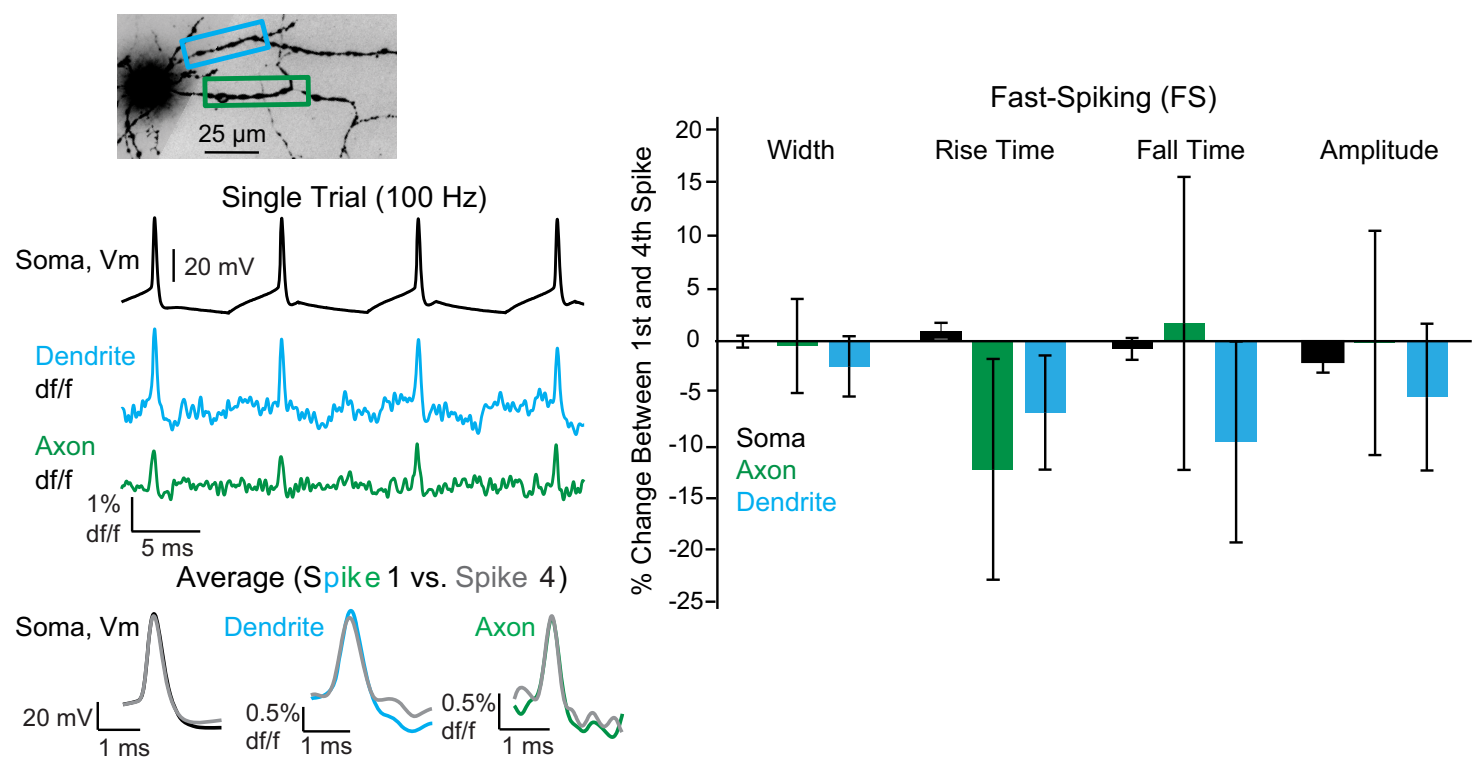

\section{B $\quad S O M(R S)$}

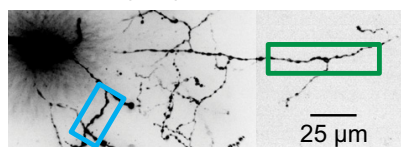

Single Trial $(100 \mathrm{~Hz})$

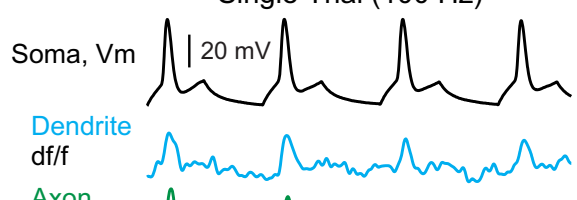

Axon $\mathrm{df} / \mathrm{f}$

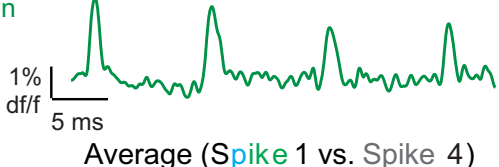

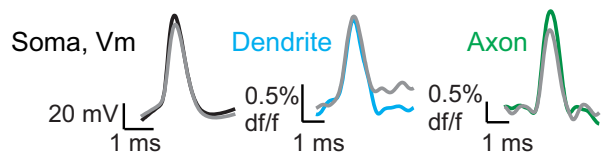

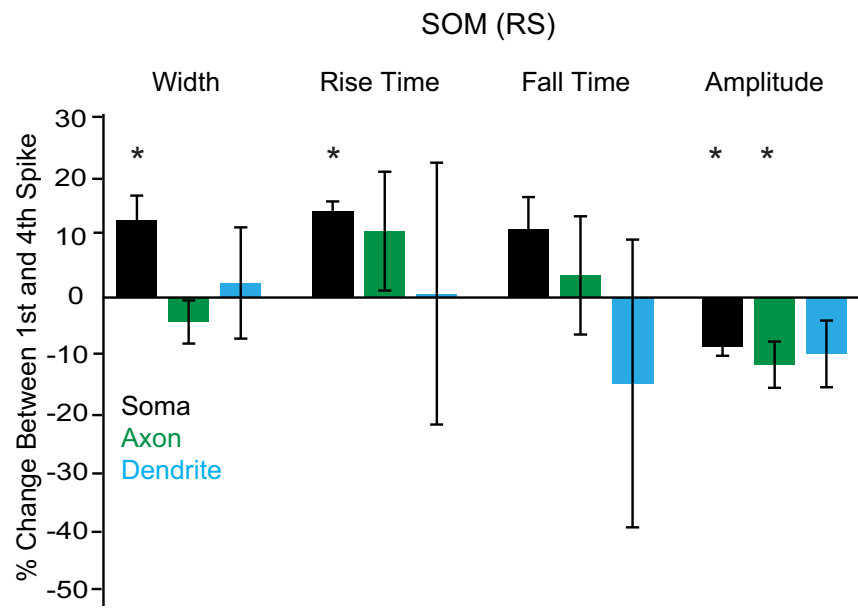

Figure 4. Action potentials in both SOM-expressing (RS) and FS interneurons travel into the axon and dendrite with repetitive stimulation. $\boldsymbol{A}$, Morphology and recording regions of a FS interneuron. Somatic current injections (4 step injections lasting $5 \mathrm{~ms}$ at $100 \mathrm{~Hz}$ ) were used to elicit action potentials. All four action potentials invade both the dendrite and axon. Bottom, Single trials and overlay of the average first and fourth action potentials ( 2 trial average). Right, Average percentage change in somatic, axonal, and dendritic action potential kinetics between the first and fourth action potential. $\boldsymbol{B}$, Same as in $\boldsymbol{A}$, except for SOM (RS) interneurons (average of 2 trials for overlay). *Statistical significance at the level of $p<0.05$ (Wilcoxon signed-rank test).

tential, whereas subsequent addition of TEA led to a $116 \%$ increase in axonal action potential duration. Double occlusion experiments with IBTX and TEA also confirmed that these two antagonists have different effects on action potential kinetics. TEA in the presence of IBTX caused an enhanced broadening of the axonal action potential compared with IBTX alone (72.3 \pm $41 \%$ increase in duration; $n=3$; TEA plus IBTX vs IBTX alone). In contrast with SOM (RS) interneurons, application of IBTX to FS interneurons did not significantly change action potential duration at the axon or soma (Fig. 5; axon, $12.3 \pm 10.6 \%, n=5$; soma, $19.9 \pm 9.9 \%, n=5 ; p>0.1$, all compartments, one-tailed Wilcoxon signed-rank test).

These results indicate that SOM-expressing (RS) and FS interneurons possess differing distributions of $\mathrm{K}^{+}$channel subtypes in their axonal and somatic compartments.
We have previously shown that the presence of Kv1 channels in the axons of pyramidal cells causes the duration of these spikes to be sensitive to somatic steady-state depolarization (Shu et al., 2006; Kole et al., 2007; Foust et al., 2011). Next, we examined whether or not a similar phenomenon may occur in SOMexpressing (RS) or FS interneuron axons because the action potentials in these cells also depend upon $\alpha$-DTX-sensitive Kv1 channels.

\section{Somatic subthreshold depolarizations influence action potential shape in SOM-expressing (RS) but not FS cells} To examine whether axonal action potential duration in SOMexpressing (RS) and FS interneurons is sensitive to somatic depolarization, we imaged single action potentials evoked with a short (5 ms) depolarizing current pulse while the cell body was 
A

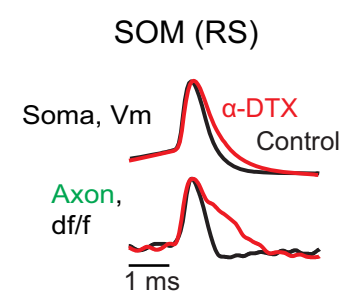

Soma, Vm
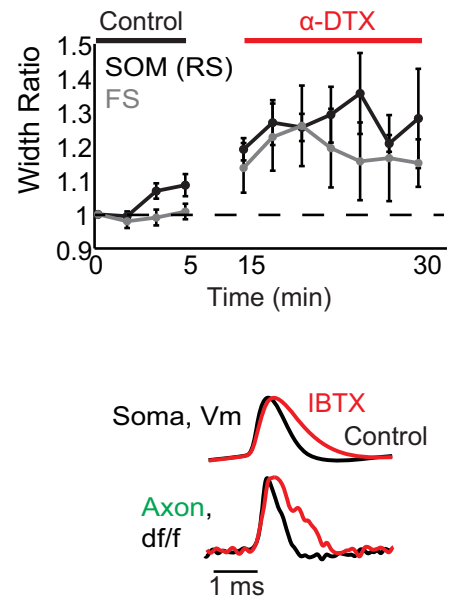

Soma, Vm

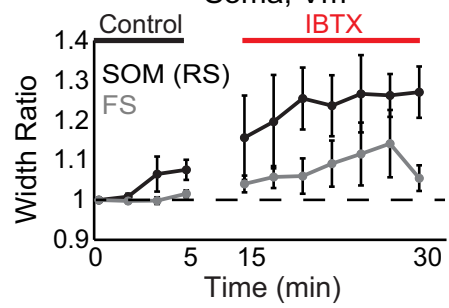

a-DTX

Fast-Spiking (FS)
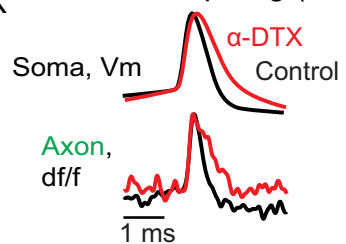

Axon, df/f

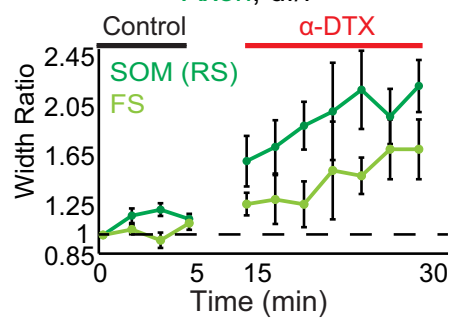

IBTX

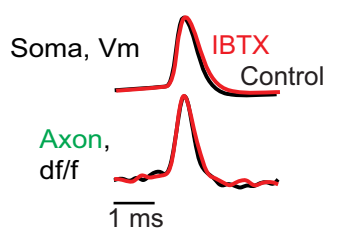

Axon, $d f / f$

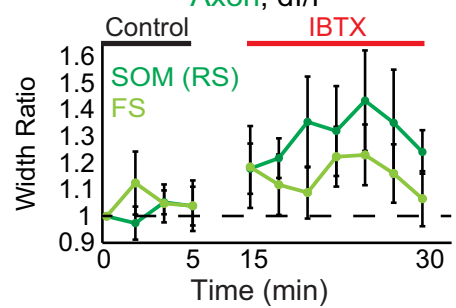

TEA

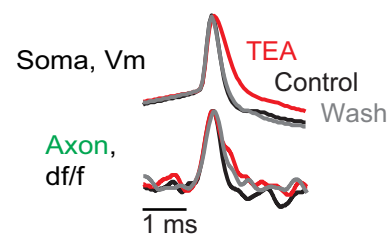

Axon, df/f

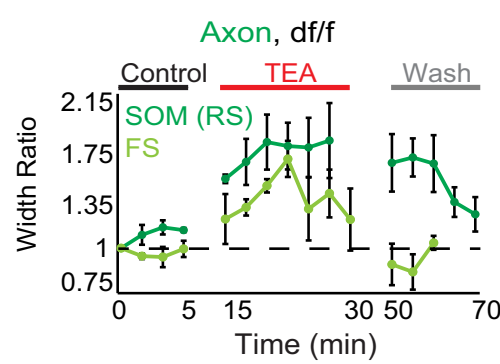

B

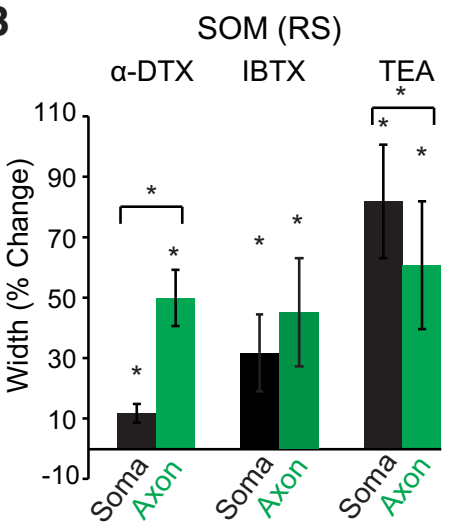

Fast-Spiking (FS)

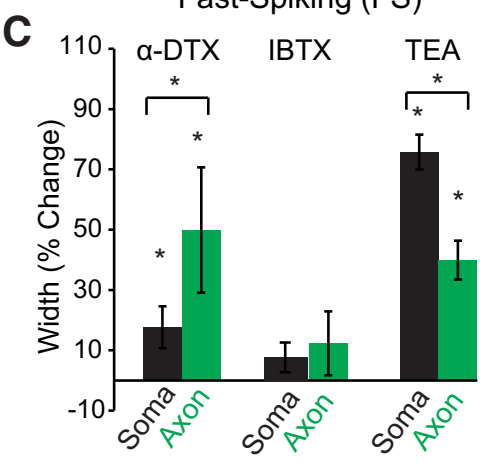

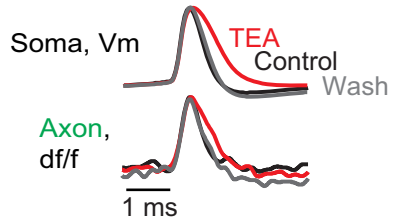

Soma, Vm

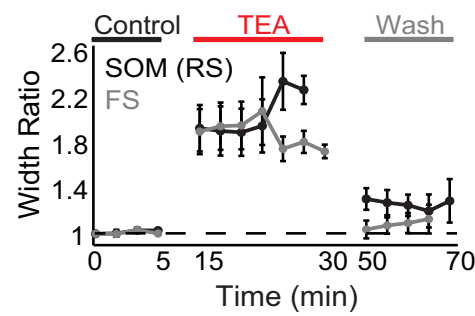

Figure 5. Somatic and axonal compartments of SOM-expressing (RS) and FS interneurons exhibit differences in sensitivity to potassium channel toxins. $A$, Examples of action potential waveforms recorded electrically at the soma or optically in the axon during control (black), drug (red), and wash (gray) conditions for each cell type and toxin. Beneath single trial examples are average population time dependence plots of somatic and axonal recordings for each drug and each cell type. Each point shows the average \pm SEM width ratio (i.e., the average width over the test population at a given time point compared with the average width of the test population at the start of the experiment) of a single trial recorded across the test population at different time points during control, drug, and washout conditions. Concentrations: $1 \mathrm{~mm}$ TEA, $100 \mathrm{~nm}$ IBTX, $100 \mathrm{~nm} \alpha$-DTX. SOM IBTX and FS $\alpha$-DTX were recorded at an optical sampling frequency of $20 \mathrm{kHz}$. Optical and electrical traces are normalized to peaks. Optical traces are averages of between two and eight trials. $\boldsymbol{B}$, Summary of drug effects on the action potential width at half-height expressed as a percentage of control values (average \pm SEM) for each SOM interneuron compartment (black represents soma; green represents axon). $\boldsymbol{C}$, Same as in $\boldsymbol{B}$, but for FS interneuron compartments. *Statistical significance at $p<0.05$ (one-tailed Wilcoxon signed-rank test for within compartment comparisons and two-tailed Wilcoxon signed-rank test for across compartment comparisons). 
A
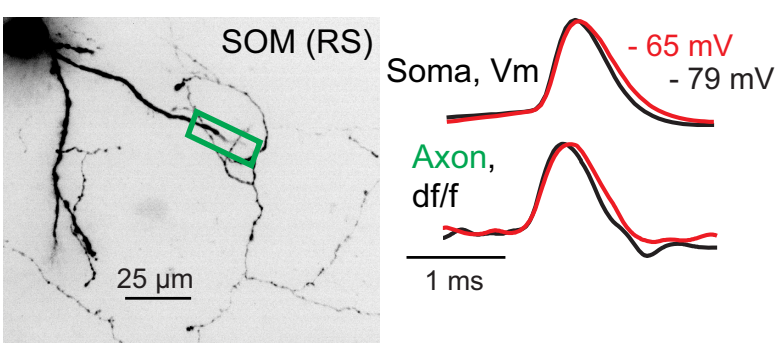

B
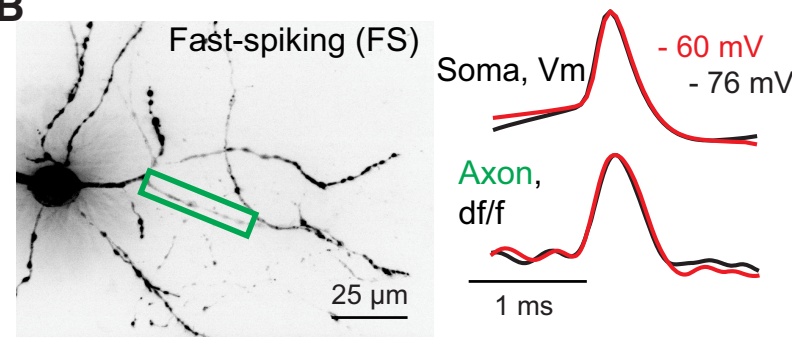

C

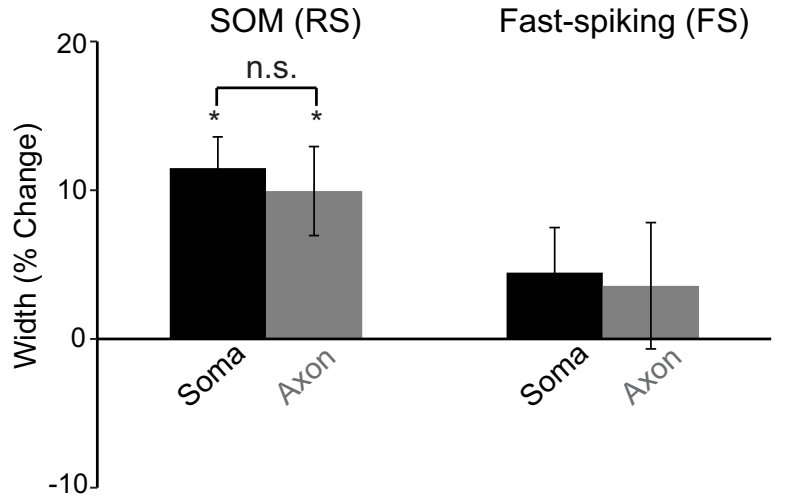

Figure 6. Subthreshold somatic depolarization significantly increases the duration of action potentials in SOM-expressing (RS) but not FS interneurons. $\boldsymbol{A}, \boldsymbol{B}$, Left, Confocal Z-projections of VSD-filled SOM (RS) and FS interneurons. Colored boxes represent regions of the axon imaged to assess action potential kinetics. $\boldsymbol{A}, \boldsymbol{B}$, Right, Average fluorescence traces [SOM (RS), 4 trial average; FS, 7 trial average], in response to somatically generated action potentials recorded optically in the axon or electrically at the soma at depolarized (red) or resting membrane potentials (black). C, Bar graphs represent the average percentage change in action potential duration at the soma and axon in response to subthreshold depolarization. Although depolarization of the soma causes a statistically significant increase in action potential duration in SOM somata and axons ( ${ }^{*} p<0.05$ ), there was no significant difference between these compartments $(p>0.05)$. Optical and electrical traces are normalized to peaks. n.s., Not significant.

either at resting membrane potential or depolarized by $10-20$ $\mathrm{mV}$ to near firing threshold for at least $10 \mathrm{~s}$ (Fig. 6).

In response to $10 \mathrm{~s}$ somatic depolarization to just below action potential threshold, action potentials in SOM-expressing (RS) interneurons underwent a small but significant broadening in the soma and axon compared with action potentials generated at resting membrane potentials (Fig. 6 ; soma, $11.5 \pm 2.1 \%, n=5$; axon, $9.9 \pm 2.9 \%, n=5 ; p<0.05$, all compartments, one-tailed Wilcoxon signed-rank test). In cortical pyramidal neurons, this effect of somatic depolarization on axonal spike duration is distance-dependent, falling off to a negligible effect after $\sim 300$ $\mu \mathrm{m}$ (Shu et al., 2006; Foust et al., 2011). The effect we observed here was present in all axonal ROIs examined (27-197 $\mu \mathrm{m}$ from the soma). These results suggest that subthreshold depolarization may work to inactivate the Kv1-type channels at the axon and the soma of SOM-expressing (RS) interneurons in a way similar to that in pyramidal cells.
In contrast to our results from SOM-expressing (RS) and pyramidal cells, FS cells did not exhibit a significant increase in action potential duration at the soma or the axon in response to sustained (10 s) somatic subthreshold depolarizations (Fig. 6; soma, $4.5 \pm 3 \%$; axon, $3.6 \pm 4.2 \% ; n=5 ; p>0.05$, one-tailed Wilcoxon signed-rank test; axonal distances of $76-150 \mu \mathrm{m})$.

\section{Discussion}

Previous intrasomatic recordings revealed that different types of interneurons in the neocortex exhibit unique electrophysiological properties (Kawaguchi, 1993a,b, 1995; Kawaguchi and Kubota, 1996, 1997; Ascoli et al., 2008; Klausberger and Somogyi, 2008; Helm et al., 2013; Perrenoud et al., 2013). However, because axonal and dendritic electrical properties of cortical neurons differ significantly from those of their somata (Martina et al., 2000; Kaiser et al., 2001; Kole et al., 2007; Shu et al., 2007b; Yu et al., 2008; Hu et al., 2010; Nörenberg et al., 2010), somatic recordings likely do not provide a complete picture of how each cell type is adapted to fulfill its role in network function. Here, using high $\mathrm{S} / \mathrm{N}$, spatial, and temporal resolution VSD imaging, we demonstrate that two major subcategories of cortical interneurons differ significantly in their axonal and dendritic properties for action potential generation and propagation.

\section{SOM and FS interneurons differ in their action potential duration in all compartments}

One of the striking physiological features of FS interneurons is the generation of relatively short duration somatic action potentials (McCormick et al., 1985; Nowak et al., 2003), whereas SOMexpressing interneurons exhibit regular spiking physiological properties, generating broader somatic action potentials (Halabisky et al., 2006; Ma et al., 2006; Kubota et al., 2011). Remarkably, we found that these differences in action potential duration were maintained throughout the axonal arbors of these two cell types. These results support the hypothesis that the electrical properties of subcellular compartments are specialized for the functional roles of each cell type (Martina et al., 2000; Hu et al., 2010, 2014; Nörenberg et al., 2010; Hu and Jonas, 2014). Because spike duration is a key feature determining calcium entry in presynaptic terminals, and thus neurotransmitter release dynamics (Sabatini and Regehr, 1997, 1999), the differences in axonal action potential waveform we have observed may reflect, in part, the mechanism by which synaptic strength and timing is adapted to the differential connectivity and functionality of these two interneuron subtypes.

\section{SOM and FS interneurons differ in their sensitivity to $\mathrm{K}^{+}$ channel blockers}

Our pharmacological investigations suggested that both SOMexpressing (RS) and FS interneurons depend upon Kv1 channels for spike repolarization throughout their axonal arbors because bath application of $\alpha$-DTX resulted in significant broadening of axonal action potentials in both cell types. In contrast, block of Kv1 channels with $\alpha$-DTX resulted in relatively small (11\%$18 \%$ ) increases in somatic (see also Zhang and McBain, 1995a,b; Goldberg et al., 2008) action potential duration in both types of interneuron. These results are consistent with the presence of Kv1 channels in the axon initial segments of parvalbumin and nonparvalbumin-containing interneurons in the cortex (Chow et al., 1999; Goldberg et al., 2008; Campanac et al., 2013), and the presence of Kv1 in axons of a wide variety of cell types in the brain (Wang et al., 1994; Veh et al., 1995; Rasband et al., 1998; Erisir et al., 1999; Wang et al., 1999; Southan and Robertson, 2000; Lambe 
and Aghajanian, 2001; Monaghan et al., 2001; Ishikawa et al., 2003; Devaux et al., 2004; Goldberg et al., 2005; Guan et al., 2006; Inda et al., 2006; Kole et al., 2007; Shu et al., 2007b; Goldberg et al., 2008; Lorincz and Nusser, 2008; Rasband, 2010; Debanne et al., 2011; Foust et al., 2011; Bender and Trussell, 2012), and is similar to the dependence of layer 5 pyramidal cells on Kv1 channels for spike repolarization in their axons, but not somata (Kole et al., 2007; Shu et al., 2007b; Foust et al., 2011).

Our studies also suggest a dependence of SOM-expressing (RS), but not FS, somata and axons on $\mathrm{BK} \mathrm{Ca}^{2+}$-activated $\mathrm{K}^{+}$ channels for spike repolarization because the application of IBTX, a relatively specific blocker of BK channels, resulted in a significant broadening of SOM somatic and axonal action potentials (Fig. 5). Similarly, we have demonstrated that the axon initial segment of neocortical layer 5 pyramidal neurons exhibit $\mathrm{N}$ and $\mathrm{P} / \mathrm{Q} \mathrm{Ca}{ }^{2+}$ channels as well as $\mathrm{BK} \mathrm{Ca}{ }^{2+}$-activated $\mathrm{K}^{+}$currents, which contribute to normal spike repolarization (Yu et al., 2010). In this regard, SOM interneurons and layer 5 pyramidal cells appear to exhibit a similar dependence upon both Kv1 and BK $\mathrm{Ca}^{2+}$-activated $\mathrm{K}^{+}$channels for axonal spike repolarization and spike duration. One possibility is that the longer duration of action potentials in these two cell types allows for sufficient entry of $\mathrm{Ca}^{2+}$ to activate BK channels, whereas the short duration of axonal action potentials in FS interneurons, or the rapid internal buffering of $\mathrm{Ca}^{2+}$ (Collin et al., 2005; Müller et al., 2007), may prevent the activation of these channels, if present. $\mathrm{BK} \mathrm{Ca}^{2+}$ activated $\mathrm{K}^{+}$channels have been observed in axons, presynaptic terminals, and soma and dendrites of differing neuronal types (Knaus et al., 1996; Marrion and Tavalin, 1998; Wanner et al., 1999; Sah and Faber, 2002; Misonou et al., 2006; Debanne et al., 2011; Bender and Trussell, 2012) and are known to contribute to spike repolarization in the cell bodies of hippocampal somatostatin interneurons (Zhang and McBain, 1995a,b) and pyramidal cells (Lancaster and Nicoll, 1987) and at presynaptic terminals, although this may occur only following block of Kv1 channels (Hu et al., 2001).

\section{Tonic depolarization has either mild or no effects on interneuron axonal spike duration}

Previously, we and others have demonstrated that the tonic depolarization of layer 5 pyramidal cells results in a significant enhancement of synaptic transmission onto neighboring pyramidal and inhibitory cells, at least in part through broadening of axonal action potential duration and subsequent increases in presynaptic spike-triggered $\mathrm{Ca}^{2+}$ transients (Shu et al., 2006, 2007b; Kole et al., 2007; Yu et al., 2010; Foust et al., 2011; Zhu et al., 2011), although a role for depolarization-induced increases in baseline $\mathrm{Ca}^{2+}$ levels is also likely (Awatramani et al., 2005; Yu et al., 2010). Depolarization of FS and SOM interneurons revealed significant enhancement in only a minority of synaptic connections between these cells and neighboring pyramidal cells (Zhu et al., 2011). This lack of effect of somatic depolarization on synaptic transmission from these two types of inhibitory interneuron is consistent with our finding that depolarization has no significant effect on axonal spike duration in FS interneurons but inconsistent with our finding that SOM axonal spike duration is lengthened by this manipulation (Fig. 6). One possibility is that the distance between SOM somata and their axonal connections with the distal dendrites of nearby pyramidal cells is too far for the somatic depolarization-induced broadening of axonal action potential duration to propagate to the appropriate presynaptic terminals because this effect falls off rapidly with distance (Foust et al., 2011).
In conclusion, it has previously been recognized that different subtypes of cortical neurons exhibit unique electrophysiological features, as revealed by intrasomatic recordings (Ascoli et al., 2008). These variations in electrophysiological features contribute to unique roles for each cell type in the operation of local cortical networks (Somogyi and Klausberger, 2005; Klausberger and Somogyi, 2008; Hu and Jonas, 2014). Dendritic recordings from FS interneurons reveal that their dendrites are markedly different from those of layer 5 pyramidal cells, with the former being tuned for the accurate conveyance of high-frequency synaptic inputs (Hu et al., 2010; Nörenberg et al., 2010), and relatively poor propagation of action potentials (Hu et al., 2010). Somatostatin interneurons, in contrast, exhibit strong and rapid dendritic propagation of action potentials (Martina et al., 2000; Kaiser et al., 2001). These results suggest that the unique electrophysiological properties of each cell type extend from the soma to the dendrite. By comparing two of the major subcategories of inhibitory interneuron in the cortex (SOM and FS), we have used a complimentary technique to confirm a diversity of somatic and dendritic electrical properties and, in addition, extend this characterization to the axonal arbor ( $\mathrm{Hu}$ and Jonas, 2014). These results indicate that all subcompartments, be they dendritic, somatic, or axonal, are uniquely tuned between cell types, in alignment with their diverse roles in cortical network function.

\section{References}

Ascoli GA, Alonso-Nanclares L, Anderson SA, Barrionuevo G, BenavidesPiccione R, Burkhalter A, Buzsáki G, Cauli B, Defelipe J, Fairén A, Feldmeyer D, Fishell G, Fregnac Y, Freund TF, Gardner D, Gardner EP, Goldberg JH, Helmstaedter M, Hestrin S, Karube F, et al. (2008) Petilla terminology: nomenclature of features of GABAergic interneurons of the cerebral cortex. Nat Rev Neurosci 9:557-568. CrossRef Medline

Awatramani GB, Price GD, Trussell LO (2005) Modulation of transmitter release by presynaptic resting potential and background calcium levels. Neuron 48:109-121. CrossRef Medline

Bender KJ, Trussell LO (2012) The physiology of the axon initial segment. Annu Rev Neurosci 35:249-265. CrossRef Medline

Binzegger T, Douglas RJ, Martin KA (2004) A quantitative map of the circuit of cat primary visual cortex. J Neurosci 24:8441-8453. CrossRef Medline

Binzegger T, Douglas RJ, Martin KA (2005) Axons in cat visual cortex are topologically self-similar. Cereb Cortex 15:152-165. CrossRef Medline

Campanac E, Gasselin C, Baude A, Rama S, Ankri N, Debanne D (2013) Enhanced intrinsic excitability in basket cells maintains excitatoryinhibitory balance in hippocampal circuits. Neuron 77:712-722. CrossRef Medline

Canepari M, Djurisic M, Zecevic D (2007) Dendritic signals from rat hippocampal CA1 pyramidal neurons during coincident pre- and postsynaptic activity: a combined voltage- and calcium-imaging study. J Physiol 580:463-484. CrossRef Medline

Canepari M, Willadt S, Zecevic D, Vogt KE (2010) Imaging inhibitory synaptic potentials using voltage sensitive dyes. Biophys J 98:2032-2040. CrossRef Medline

Casale AE, McCormick DA (2011) Active action potential propagation but not initiation in thalamic interneuron dendrites. J Neurosci 31:1828918302. CrossRef Medline

Chow A, Erisir A, Farb C, Nadal MS, Ozaita A, Lau D, Welker E, Rudy B (1999) $\mathrm{K}(+)$ channel expression distinguishes subpopulations of parvalbumin- and somatostatin-containing neocortical interneurons. J Neurosci 19:9332-9345. Medline

Coetzee WA, Amarillo Y, Chiu J, Chow A, Lau D, McCormack T, Moreno H, Nadal MS, Ozaita A, Pountney D, Saganich M, Vega-Saenz de Miera E, Rudy B (1999) Molecular diversity of $\mathrm{K}^{+}$channels. Ann N Y Acad Sci 868:233-285. CrossRef Medline

Collin T, Chat M, Lucas MG, Moreno H, Racay P, Schwaller B, Marty A, Llano I (2005) Developmental changes in parvalbumin regulate presynaptic $\mathrm{Ca}^{2+}$ signaling. J Neurosci 25:96-107. CrossRef Medline

Debanne D, Campanac E, Bialowas A, Carlier E, Alcaraz G (2011) Axon physiology. Physiol Rev 91:555-602. CrossRef Medline 
Devaux JJ, Kleopa KA, Cooper EC, Scherer SS (2004) KCNQ2 is a nodal $\mathrm{K}^{+}$ channel. J Neurosci 24:1236-1244. CrossRef Medline

Djurisic M, Antic S, Chen WR, Zecevic D (2004) Voltage imaging from dendrites of mitral cells: EPSP attenuation and spike trigger zones. J Neurosci 24:6703-6714. CrossRef Medline

Erisir A, Lau D, Rudy B, Leonard CS (1999) Function of specific K(+) channels in sustained high-frequency firing of fast-spiking neocortical interneurons. J Neurophysiol 82:2476-2489. Medline

Foust A, Popovic M, Zecevic D, McCormick DA (2010) Action potentials initiate in the axon initial segment and propagate through axon collaterals reliably in cerebellar Purkinje neurons. J Neurosci 30:6891-6902. CrossRef Medline

Foust AJ, Yu Y, Popovic M, Zecevic D, McCormick DA (2011) Somatic membrane potential and Kvl channels control spike repolarization in cortical axon collaterals and presynaptic boutons. J Neurosci 31:1549015498. CrossRef Medline

Goldberg EM, Watanabe S, Chang SY, Joho RH, Huang ZJ, Leonard CS, Rudy B (2005) Specific functions of synaptically localized potassium channels in synaptic transmission at the neocortical GABAergic fast-spiking cell synapse. J Neurosci 25:5230-5235. CrossRef Medline

Goldberg EM, Clark BD, Zagha E, Nahmani M, Erisir A, Rudy B (2008) $\mathrm{K}^{+}$ channels at the axon initial segment dampen near-threshold excitability of neocortical fast-spiking GABAergic interneurons. Neuron 58:387-400. CrossRef Medline

Guan D, Lee JC, Tkatch T, Surmeier DJ, Armstrong WE, Foehring RC (2006) Expression and biophysical properties of Kvl channels in supragranular neocortical pyramidal neurones. J Physiol 571:371-389. CrossRef Medline

Halabisky B, Shen F, Huguenard JR, Prince DA (2006) Electrophysiological classification of somatostatin-positive interneurons in mouse sensorimotor cortex. J Neurophysiol 96:834-845. CrossRef Medline

Helm J, Akgul G, Wollmuth LP (2013) Subgroups of parvalbuminexpressing interneurons in layers $2 / 3$ of the visual cortex. J Neurophysiol 109:1600-1613. CrossRef Medline

$\mathrm{Hu} \mathrm{H}$, Jonas $\mathrm{P}$ (2014) A supercritical density of $\mathrm{Na}(+)$ channels ensures fast signaling in GABAergic interneuron axons. Nat Neurosci 17:686-693. CrossRef Medline

Hu H, Shao LR, Chavoshy S, Gu N, Trieb M, Behrens R, Laake P, Pongs O, Knaus HG, Ottersen OP, Storm JF (2001) Presynaptic $\mathrm{Ca}^{2+}$-activated $\mathrm{K}^{+}$channels in glutamatergic hippocampal terminals and their role in spike repolarization and regulation of transmitter release. J Neurosci 21: 9585-9597. Medline

Hu H, Martina M, Jonas P (2010) Dendritic mechanisms underlying rapid synaptic activation of fast-spiking hippocampal interneurons. Science 327:52-58. CrossRef Medline

Hu H, Gan J, Jonas P (2014) Interneurons: fast-spiking, parvalbumin(+) GABAergic interneurons: from cellular design to microcircuit function. Science 345:1255263. CrossRef Medline

Inda MC, DeFelipe J, Muñoz A (2006) Voltage-gated ion channels in the axon initial segment of human cortical pyramidal cells and their relationship with chandelier cells. Proc Natl Acad Sci U S A 103:2920-2925. CrossRef Medline

Ishikawa T, Nakamura Y, Saitoh N, Li WB, Iwasaki S, Takahashi T (2003) Distinct roles of Kv1 and Kv3 potassium channels at the calyx of Held presynaptic terminal. J Neurosci 23:10445-10453. Medline

Kaiser KM, Zilberter Y, Sakmann B (2001) Back-propagating action potentials mediate calcium signalling in dendrites of bitufted interneurons in layer 2/3 of rat somatosensory cortex. J Physiol 535:17-31. CrossRef Medline

Kawaguchi Y (1993a) Groupings of nonpyramidal and pyramidal cells with specific physiological and morphological characteristics in rat frontal cortex. J Neurophysiol 69:416-431. Medline

Kawaguchi Y (1993b) Physiological, morphological, and histochemical characterization of three classes of interneurons in rat neostriatum. J Neurosci 13:4908-4923. Medline

Kawaguchi Y (1995) Physiological subgroups of nonpyramidal cells with specific morphological characteristics in layer II/III of rat frontal cortex. J Neurosci 15:2638-2655. Medline

Kawaguchi Y, Kubota Y (1996) Physiological and morphological identification of somatostatin- or vasoactive intestinal polypeptide-containing cells among GABAergic cell subtypes in rat frontal cortex. J Neurosci 16: 2701-2715. Medline
Kawaguchi Y, Kubota Y (1997) GABAergic cell subtypes and their synaptic connections in rat frontal cortex. Cereb Cortex 7:476-486. CrossRef Medline

Klausberger T, Somogyi P (2008) Neuronal diversity and temporal dynamics: the unity of hippocampal circuit operations. Science 321:53-57. CrossRef Medline

Knaus HG, Schwarzer C, Koch RO, Eberhart A, Kaczorowski GJ, Glossmann H, Wunder F, Pongs O, Garcia ML, Sperk G (1996) Distribution of high-conductance $\mathrm{Ca}(2+)$-activated $\mathrm{K}^{+}$channels in rat brain: targeting to axons and nerve terminals. J Neurosci 16:955-963. Medline

Kole MH, Letzkus JJ, Stuart GJ (2007) Axon initial segment Kv1 channels control axonal action potential waveform and synaptic efficacy. Neuron 55:633-647. CrossRef Medline

Kubota Y, Shigematsu N, Karube F, Sekigawa A, Kato S, Yamaguchi N, Hirai Y, Morishima M, Kawaguchi Y (2011) Selective coexpression of multiple chemical markers defines discrete populations of neocortical GABAergic neurons. Cereb Cortex 21:1803-1817. CrossRef Medline

Lambe EK, Aghajanian GK (2001) The role of Kv1.2-containing potassium channels in serotonin-induced glutamate release from thalamocortical terminals in rat frontal cortex. J Neurosci 21:9955-9963. Medline

Lancaster B, Nicoll RA (1987) Properties of two calcium-activated hyperpolarizations in rat hippocampal neurones. J Physiol 389:187-203. CrossRef Medline

Li T, Tian C, Scalmani P, Frassoni C, Mantegazza M, Wang Y, Yang M, Wu S, Shu Y (2014) Action potential initiation in neocortical inhibitory interneurons. PLoS Biol 12:e1001944. CrossRef Medline

Lorincz A, Nusser Z (2008) Cell-type-dependent molecular composition of the axon initial segment. J Neurosci 28:14329-14340. CrossRef Medline

Ma Y, Hu H, Berrebi AS, Mathers PH, Agmon A (2006) Distinct subtypes of somatostatin-containing neocortical interneurons revealed in transgenic mice. J Neurosci 26:5069-5082. CrossRef Medline

Marrion NV, Tavalin SJ (1998) Selective activation of $\mathrm{Ca}^{2+}$-activated $\mathrm{K}^{+}$ channels by localized $\mathrm{Ca}^{2+}$ channels in hippocampal neurons. Nature 395:900-905. CrossRef Medline

Martina M, Vida I, Jonas P (2000) Distal initiation and active propagation of action potentials in interneuron dendrites. Science 287:295-300. CrossRef Medline

McCormick DA, Connors BW, Lighthall JW, Prince DA (1985) Comparative electrophysiology of pyramidal and sparsely spiny stellate neurons of the neocortex. J Neurophysiol 54:782-806. Medline

McGarry LM, Packer AM, Fino E, Nikolenko V, Sippy T, Yuste R (2010) Quantitative classification of somatostatin-positive neocortical interneurons identifies three interneuron subtypes. Front Neural Circuits 4:12. CrossRef Medline

Misonou H, Menegola M, Buchwalder L, Park EW, Meredith A, Rhodes KJ, Aldrich RW, Trimmer JS (2006) Immunolocalization of the $\mathrm{Ca}^{2+}$ activated $\mathrm{K}^{+}$channel Slo1 in axons and nerve terminals of mammalian brain and cultured neurons. J Comp Neurol 496:289-302. CrossRef Medline

Monaghan MM, Trimmer JS, Rhodes KJ (2001) Experimental localization of Kv1 family voltage-gated $\mathrm{K}^{+}$channel alpha and beta subunits in rat hippocampal formation. J Neurosci 21:5973-5983. Medline

Müller M, Felmy F, Schwaller B, Schneggenburger R (2007) Parvalbumin is a mobile presynaptic $\mathrm{Ca}^{2+}$ buffer in the calyx of held that accelerates the decay of $\mathrm{Ca}^{2+}$ and short-term facilitation. J Neurosci 27:2261-2271. CrossRef Medline

Nörenberg A, Hu H, Vida I, Bartos M, Jonas P (2010) Distinct nonuniform cable properties optimize rapid and efficient activation of fast-spiking GABAergic interneurons. Proc Natl Acad Sci U S A 107:894-899. CrossRef Medline

Nowak LG, Azouz R, Sanchez-Vives MV, Gray CM, McCormick DA (2003) Electrophysiological classes of cat primary visual cortical neurons in vivo as revealed by quantitative analyses. J Neurophysiol 89:1541-1566. CrossRef Medline

Oliva AA Jr, Jiang M, Lam T, Smith KL, Swann JW (2000) Novel hippocampal interneuronal subtypes identified using transgenic mice that express green fluorescent protein in GABAergic interneurons. J Neurosci 20: 3354-3368. Medline

Perrenoud Q, Rossier J, Geoffroy H, Vitalis T, Gallopin T (2013) Diversity of GABAergic interneurons in layer VIa and VIb of mouse barrel cortex. Cereb Cortex 23:423-441. CrossRef Medline

Popovic MA, Foust AJ, McCormick DA, Zecevic D (2011) The spatio- 
temporal characteristics of action potential initiation in layer 5 pyramidal neurons: a voltage imaging study. J Physiol 589:4167-4187. CrossRef Medline

Rasband MN (2010) Clustered $\mathrm{K}^{+}$channel complexes in axons. Neurosci Lett 486:101-106. CrossRef Medline

Rasband MN, Trimmer JS, Schwarz TL, Levinson SR, Ellisman MH, Schachner M, Shrager P (1998) Potassium channel distribution, clustering, and function in remyelinating rat axons. J Neurosci 18:36-47. Medline

Rudy B, Fishell G, Lee S, Hjerling-Leffler J (2011) Three groups of interneurons account for nearly $100 \%$ of neocortical GABAergic neurons. Dev Neurobiol 71:45-61.

Sabatini BL, Regehr WG (1997) Control of neurotransmitter release by presynaptic waveform at the granule cell to Purkinje cell synapse. J Neurosci 17:3425-3435. Medline

Sabatini BL, Regehr WG (1999) Timing of synaptic transmission. Annu Rev Physiol 61:521-542. CrossRef Medline

Sah P, Faber ES (2002) Channels underlying neuronal calcium-activated potassium currents. Prog Neurobiol 66:345-353. CrossRef Medline

Salzberg BM, Obaid AL, Senseman DM, Gainer H (1983) Optical recording of action potentials from vertebrate nerve terminals using potentiometric probes provides evidence for sodium and calcium components. Nature 306:36-40. CrossRef Medline

Salzberg BM, Obaid AL, Bezanilla F (1993) Microsecond response of a voltage-sensitive merocyanine dye: fast voltage-clamp measurements on squid giant axon. Jpn J Physiol 43 [Suppl 1]:S37-S41.

Sekirnjak C, Martone ME, Weiser M, Deerinck T, Bueno E, Rudy B, Ellisman M (1997) Subcellular localization of the $\mathrm{K}^{+}$channel subunit Kv3.1b in selected rat CNS neurons. Brain Res 766:173-187. CrossRef Medline

Shao LR, Halvorsrud R, Borg-Graham L, Storm JF (1999) The role of BKtype $\mathrm{Ca}^{2+}$-dependent $\mathrm{K}^{+}$channels in spike broadening during repetitive firing in rat hippocampal pyramidal cells. J Physiol 521:135-146. CrossRef Medline

Shu Y, Hasenstaub A, Duque A, Yu Y, McCormick DA (2006) Modulation of intracortical synaptic potentials by presynaptic somatic membrane potential. Nature 441:761-765. CrossRef Medline

Shu Y, Duque A, Yu Y, Haider B, McCormick DA (2007a) Properties of action potential initiation in neocortical pyramidal cells: evidence from whole cell axon recordings. J Neurophysiol 97:746-760. CrossRef Medline

Shu Y, Yu Y, Yang J, McCormick DA (2007b) Selective control of cortical axonal spikes by a slowly inactivating $\mathrm{K}+$ current. Proc Natl Acad Sci U S A 104:11453-11458. CrossRef Medline

Somogyi P, Klausberger T (2005) Defined types of cortical interneurone structure space and spike timing in the hippocampus. J Physiol 562:9-26. CrossRef Medline

Southan AP, Robertson B (2000) Electrophysiological characterization of voltage-gated $\mathrm{K}(+)$ currents in cerebellar basket and purkinje cells: Kv1 and Kv3 channel subfamilies are present in basket cell nerve terminals. J Neurosci 20:114-122. Medline

Stuart GJ, Sakmann B (1994) Active propagation of somatic action potentials into neocortical pyramidal cell dendrites. Nature 367:69-72. CrossRef Medline

Stuart G, Schiller J, Sakmann B (1997) Action potential initiation and propagation in rat neocortical pyramidal neurons. J Physiol 505:617-632. CrossRef Medline
Szabadics J, Varga C, Molnár G, Oláh S, Barzó P, Tamás G (2006) Excitatory effect of GABAergic axo-axonic cells in cortical microcircuits. Science 311:233-235. CrossRef Medline

Tahvildari B, Wölfel M, Duque A, McCormick DA (2012) Selective functional interactions between excitatory and inhibitory cortical neurons and differential contribution to persistent activity of the slow oscillation. J Neurosci 32:12165-12179. CrossRef Medline

Trimmer JS, Rhodes KJ (2004) Localization of voltage-gated ion channels in mammalian brain. Annu Rev Physiol 66:477-519. CrossRef Medline

Veh RW, Lichtinghagen R, Sewing S, Wunder F, Grumbach IM, Pongs O (1995) Immunohistochemical localization of five members of the Kv1 channel subunits: contrasting subcellular locations and neuron-specific co-localizations in rat brain. Eur J Neurosci 7:2189-2205. CrossRef Medline

Wang FC, Parcej DN, Dolly JO (1999) alpha subunit compositions of Kv1.1-containing $\mathrm{K}^{+}$channel subtypes fractionated from rat brain using dendrotoxins. Eur J Biochem 263:230-237. CrossRef Medline

Wang H, Kunkel DD, Schwartzkroin PA, Tempel BL (1994) Localization of Kv1.1 and Kv1.2, two K channel proteins, to synaptic terminals, somata, and dendrites in the mouse brain. J Neurosci 14:4588-4599. Medline

Wang Y, Gupta A, Toledo-Rodriguez M, Wu CZ, Markram H (2002) Anatomical, physiological, molecular and circuit properties of nest basket cells in the developing somatosensory cortex. Cereb Cortex 12:395-410. CrossRef Medline

Wang Y, Toledo-Rodriguez M, Gupta A, Wu C, Silberberg G, Luo J, Markram $\mathrm{H}$ (2004) Anatomical, physiological and molecular properties of Martinotti cells in the somatosensory cortex of the juvenile rat. J Physiol 561: 65-90. CrossRef Medline

Wanner SG, Koch RO, Koschak A, Trieb M, Garcia ML, Kaczorowski GJ, Knaus HG (1999) High-conductance calcium-activated potassium channels in rat brain: pharmacology, distribution, and subunit composition. Biochemistry 38:5392-5400. CrossRef Medline

Xu X, Roby KD, Callaway EM (2006) Mouse cortical inhibitory neuron type that coexpresses somatostatin and calretinin. J Comp Neurol 499:144160. CrossRef Medline

Xu X, Roby KD, Callaway EM (2010) Immunochemical characterization of inhibitory mouse cortical neurons: three chemically distinct classes of inhibitory cells. J Comp Neurol 518:389-404. CrossRef Medline

Yu Y, Shu Y, McCormick DA (2008) Cortical action potential backpropagation explains spike threshold variability and rapid-onset kinetics. J Neurosci 28:7260-7272. CrossRef Medline

Yu Y, Maureira C, Liu X, McCormick D (2010) P/Q and N channels control baseline and spike-triggered calcium levels in neocortical axons and synaptic boutons. J Neurosci 30:11858-11869. CrossRef Medline

Zhang L, McBain CJ (1995a) Voltage-gated potassium currents in stratum oriens-alveus inhibitory neurones of the rat CA1 hippocampus. J Physiol 488:647-660. CrossRef Medline

Zhang L, McBain CJ (1995b) Potassium conductances underlying repolarization and after-hyperpolarization in rat CA1 hippocampal interneurones. J Physiol 488:661-672. CrossRef Medline

Zhu J, Jiang M, Yang M, Hou H, Shu Y (2011) Membrane potentialdependent modulation of recurrent inhibition in rat neocortex. PLoS Biol 9:e1001032. CrossRef Medline 